\title{
The Composition and Distribution of Volatile Organic Compounds in Sediments of the East Taijinar Salt Lake in Northern Qinghai-Tibet Plateau
}

\author{
Xiaohang $\mathrm{Lu}^{1,2,3}$, Zhe Ma ${ }^{1,2,3}$, Lei $\mathrm{Yi}^{1,2}$, Guangwu Zhang ${ }^{1,2,3}$, Fuhong Chen ${ }^{1,2,3}$ and \\ Fengqing $\operatorname{Han}^{1,2 *}$
}

${ }^{1}$ Key Laboratory of Comprehensive and Highly Efficient Utilization of Salt Lake Resources, Qinghai Institute of Salt Lakes, Chinese Academy of Sciences, Xining, China, ${ }^{2}$ Qinghai Provincial Key Laboratory of Geology and Environment of Salt Lakes, Xining, China

${ }^{3}$ Qinghai Institute of Salt Lakes, University of Chinese Academy of Sciences, Beijing, China

\section{OPEN ACCESS}

Edited by:

Fudong Liu,

University of Central Florida,

United States

Reviewed by:

Luke Kanakwengele Chimuka,

University of the Witwatersrand, South

Africa

Marta Llorca,

Instituto de Diagnóstico Ambiental y

Estudios del Agua (IDAEA), Spain

*Correspondence:

Fengqing Han

hanfq@isl.ac.cn

Specialty section: This article was submitted to

Organic Pollutants,

a section of the journal

Frontiers in Environmental Chemistry

Received: 30 April 2021

Accepted: 02 July 2021

Published: 16 July 2021

Citation:

LuX, Ma Z, Yi L, Zhang G, Chen F and Han F (2021) The Composition and

Distribution of Volatile Organic

Compounds in Sediments of the East

Taijinar Salt Lake in Northern Qinghai-

Tibet Plateau.

Front. Environ. Chem. 2:653867.

doi: 10.3389/fenvc.2021.653867
The main objective of this study was to explore the composition and distribution of volatile organic compounds (VOCs) and the factors that affect their distribution in the salt lake sediments. Thirteen sediment samples were collected from a depth profile in the East Taijinar Lake, China. VOCs of different samples were extracted by headspace solid phase microextraction. Gas chromatography-ion mobility spectrometry, gas chromatographymass spectrometry, and X-ray diffraction were used to analyze the VOCs, $n$-alkanes, and minerals present in samples. Thirty-four VOCs were identified and classified into seven types, including terpenes, furans, esters, aldehydes, ketones, alcohols, and acids, apart from six contaminants. It was found that 24 of the most prevalent compounds in clay were on average $101.45 \%$ higher than those in sandstone and halite because of the sedimentary environment, while the remaining ten (2-acetylfuran, 2-pinene D, etc.) were on average $13.27 \%$ higher in sandstone and halite sediments than in clay. This can be attributed to their different biological sources, porosity, and higher salinity. Based on the Q-cluster analysis, the 13 sediment samples were split into two groups, including the group according to composition and the group based on distribution of VOCs. In this study, it was found that the VOCs correlate positively with detrital minerals, with Group I exhibiting a high content of detrital minerals (>25\%), while Group II showed the opposite characteristics. The consumption of organic matter (OM) by microorganisms leads to the formation of VOCs in sediment. The values of carbon preference index and n-alkane further demonstrate that the organic matter of the two groups came from different sources, exogenous and endogenous. $\mathrm{Pr} / \mathrm{Ph}$ ratios, $\mathrm{Pr} / \mathrm{C} 17$, and $\mathrm{Pr} / \mathrm{C} 18$ also suggest that the $\mathrm{OM}$ in all sediments was strongly affected by microorganisms in an anoxic environment. Together, these results demonstrate that the OM from different biological sources and microbial activities played a critical role in deciding the composition and distribution of VOCs in the sediment. This study also shows that the proportion of VOCs in halite was discernably higher than that in clay and sandstone and that the content of VOCs should be considered when studying OM in salt lake sediments. 


\section{INTRODUCTION}

Volatile organic compounds (VOCs) are ubiquitous in the environment and can be of biological origin, including plants (Dudareva et al., 2013), bacteria (Mohnke and Buijten, 1993; Korpi et al., 2009; Insam and Seewald, 2010; Zhang et al., 2017), algae, and marine organisms (Whelan, 1984; Kidanu et al., 2017); or anthropogenic origin (Kuráň and Soják, 1996; Sattler et al., 2013). VOCs are regarded as atmospheric, and groundwater pollutants and are toxic (McDonald et al., 1988; Thiros, 2000; Pecoraino et al., 2008), even in salt lake brine.

The type of VOC is strongly dependent on the oxygen availability and physiological state of the microorganisms (Insam and Seewald, 2010). Moreover, VOCs supply nutrients for microbial cells and mediate intercellular interactions, and they play a critical role in regulating the diversity, compositions, and network structures of prokaryotic communities in saline sediments (Ding et al., 2020). Meanwhile, they serve important roles by acting as both a source and sink of organic compounds (Bravo-Linares and Mudge, 2007). Therefore, it is crucial to measure VOCs in salt lake sediments. The type of marine sediment also influences the type of VOCs produced. For example, more reduced species such as dimethyl sulfide and methyl mercaptan are produced in anoxic and muddy sediments (Kiene and Taylor, 1988).

The sediments of salt lakes are characterized by high salinity and the presence of toxic ions (Co., Ni, and Mn) (Liu et al., 2018; Isaji et al., 2019). These conditions result in a reduction in both the number of species contributing to the environmental biomass (Evans and Kirkland, 1988) and special microbial communities such as Proteobacteria (Dorador et al., 2018). Moreover, the source of OM in salt lake sediments is complicated and can include planktonic and benthic fauna and flora and terrestrial material from riverine and anthropogenic inputs. Notably, OM has existed in anaerobic environments for a long time, experiencing a variety of geological processes. Some of the $\mathrm{OM}$ has also been consumed by microorganisms leading to the formation of VOCs. A small portion of the remaining OM still retains geological information from the past. Due to their essential role in indicating the paleo-climate and paleoenvironment, previous studies of $\mathrm{OM}$ in salt lake sediments have mainly focused on organic carbon, humic acids (Domagalski et al., 1989), aliphatic acids (Serebrennikova et al., 2015), and organic acids (Kawamura and Nissenbaum, 1992). However, the composition and distribution of VOCs in sediments and the main factors affecting VOCs remain mostly unknown.

To date, different methodologies such as Gas Chromatography-Mass Spectrometry have been developed to assess the types and concentrations of VOCs present in sediments. A wide variety of VOCs has been detected in sediments, including $n$-alkanes, furans, ketones, aldehydes, and mono-aromatic compounds (Whelan, 1984; Visscher et al., 2003). However, most of these methods require pretreatment and solvents such as methanol, $n$-hexane, and $n$-pentane to extract VOCs from the samples (DeLeon et al., 1980; Siegrist and Jenssen, 1990; Amaral et al., 1994). In this study, gas chromatography-ion mobility spectrometry (GC-IMS) was used to analyze the VOCs within salt lake sediment samples. Notably, GC-IMS allows for the detection of VOCs in liquid or solid samples without pretreatment (Cavanna et al., 2019). This analytical technique is regarded as a rapid and accurate that provides high-resolution to identify VOCs (Armenta et al., 2011; Garrido-Delgado et al., 2015; Yuan et al., 2019).

Therefore, the aim of this study was to characterize the composition and distribution of VOCs and explore the source of $\mathrm{OM}$ in East Taijinar salt lake sediments. It was further determined if a certain regularity exists in the type and content of VOCs. Finally, the main factors that affect the distribution of VOCs were systematically explored.

\section{MATERIALS AND METHODS}

\section{Geological Background}

The East Taijinar salt lake $\left(37^{\circ} 21^{\prime} 54^{\prime \prime}-37^{\circ} 36^{\prime} 05^{\prime \prime} \mathrm{N}\right.$, $93^{\circ} 45^{\prime} 33^{\prime \prime}-94^{\circ} 06^{\prime} 48^{\prime \prime} \mathrm{W}$ ) is located in the Tertiary anticline structural depression belt in the hinterland of the Qaidam Basin (Figure 1); the salinity of lake is about 29\% (Qingsheng and Fengqing, 2013). The formation of this salt lake is associated with the uplift of the Qinghai-Tibet Plateau, the strong tectonic movement of the Qaidam Basin, and the migration of the residual salt-forming brine from the western to the central and eastern regions (Zhang et al., 1987). The East Taijinar River from the Kunlun Mountains in the southwest mainly supplies the lake. The brine is a magnesium sulfate subtype with a $\mathrm{pH}$ of 7.9 (Zheng and Liu, 2009).

The East Taijinar salt lake spans approximately $300 \mathrm{~km}^{2}$, which includes $100 \mathrm{~km}^{2}$ of the lake area and $200 \mathrm{~km}^{2}$ of dry salt flats. The dominant sediment in the upper part of the salt lake area is mainly halite. Halite is dominant among the relatively simple minerals, followed by a small amount of mirabilite and gypsum. Moreover, sulfate deposition was not developed, which indicates that the lake quickly entered the chloride deposition stage without experiencing the sulfate deposition stage (Qingsheng and Fengqing, 2013).

\section{Sample Collection}

Thirteen sediment samples (designated as DT01-DT13) were collected from a depth profile in the eastern section of the lake using a polyvinyl chloride corer. The first sample was collected at $0.5 \mathrm{~m}$ depth, with subsequent samples collected downward at intervals of $1 \mathrm{~m}$ along with a $13.5 \mathrm{~m}$ depth profile. The depth profile consisted of three sediment layers: clay (DT01-DT08), sandstone (DT09-DT11), and halite (DT12-DT13). In terms of lithology, sediments represented by samples DT01-DT08 were deposited in a relatively humid environment; those represented by DT09-DT11 were deposited in an arid environment, and those represented by DT12-DT13 were deposited in a semi-arid 


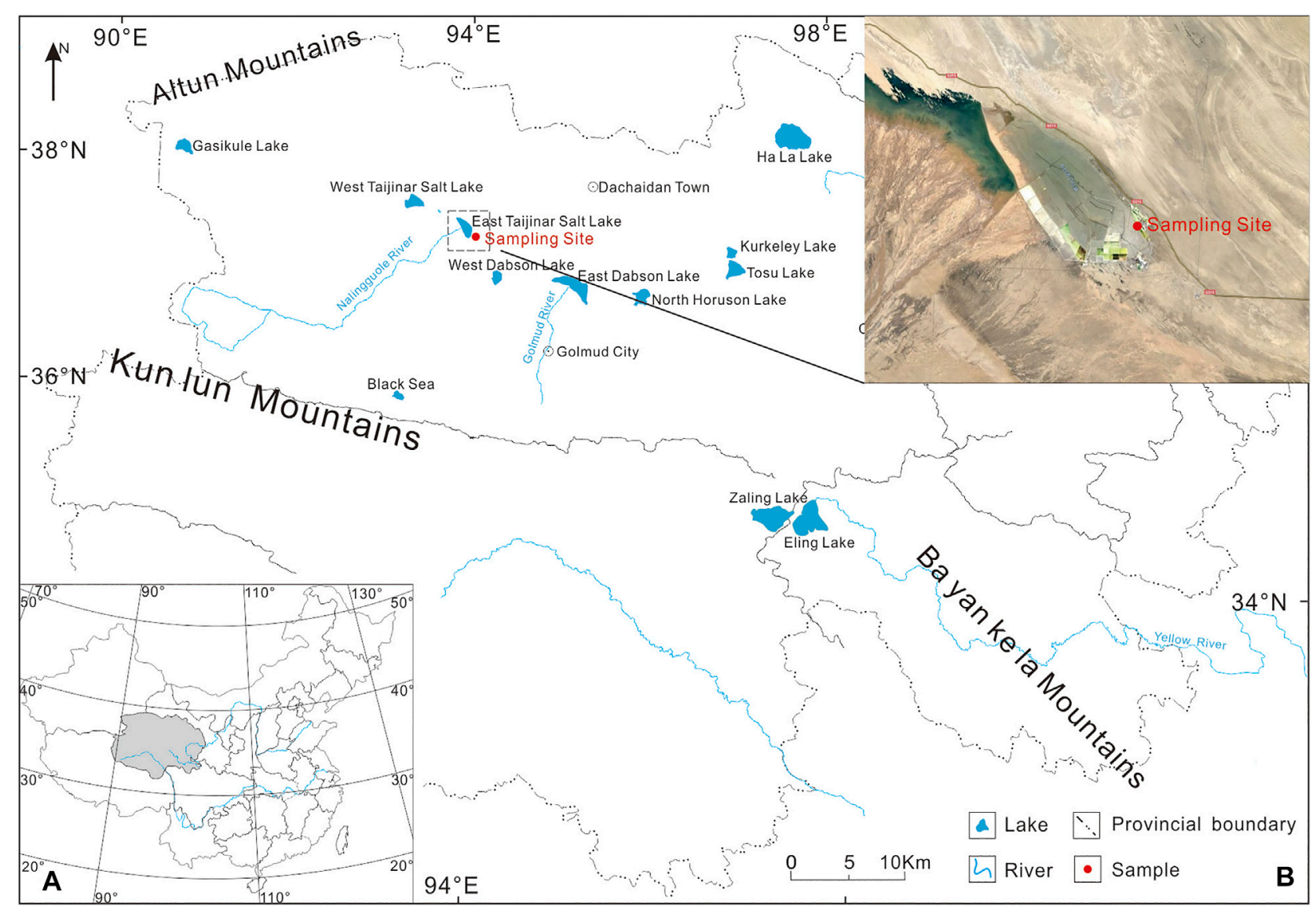

FIGURE 1 | Map of the sampling site and lakes in the Qinghai Province: (A) Map showing the location of Qinghai Province in China and (B) Map showing the location of East Taijinar Salt Lake and the sampling site in the Qinghai Province.

environment. The samples were stored in polyethylene bags and maintained at $4^{\circ} \mathrm{C}$. Prior to the analysis, samples were freezedried, ground, and then passed through a $200-\mu \mathrm{m}$ mesh sieve.

\section{Quantification of Total Organic Carbon and Volatile Organic Compounds}

The TOC fraction was quantified using two different approaches, the direct method and the subtraction method.

The direct method was performed as per the procedure provided by Wu et al. (2012), with some modifications. Briefly, the sample $(2 \mathrm{~g})$ was treated with acid, washed five times until the acid was removed, and dried in a crucible. The sample was ground to a powder using an Elementar element analyzer and decomposed at $950^{\circ} \mathrm{C}$. Finally, the mass percentage of carbon was determined. However, this method resulted in VOC loss during the acid treatment and included repeated washing and drying steps. Thus, the final value of TOC does not include VOCs.

The subtraction method was performed to quantify TOC in sediments following the procedure provided by Gao et al. (2019). First, total carbon (TC) content was measured by high-temperature catalytic oxidation. Next, the inorganic carbon (IC) content was measured by adding $\mathrm{H}_{3} \mathrm{PO}_{4}$ to convert the IC into $\mathrm{CO}_{2}$. Finally, the
TOC content was calculated using the difference between TC and IC. This method avoids VOC loss during the experiment. Thus, the value represents the TOC content, including VOCs. Each sample was tested in triplicate using both methods. The results are expressed as the average value to reduce unintentional error.

The proportion of VOCs in the TOC was calculated using Eq. 1 as follows:

$$
\omega_{V O C}=\frac{\text { TOC }_{s}-T_{O C}}{T_{O}} \times 100 \%
$$

where $\mathrm{TOC}_{\mathrm{s}}$ and $\mathrm{TOC}_{\mathrm{d}}$ represent the TOC measured by the subtraction and direct methods, respectively. The proportion of VOCs is expressed as a percentage.

\section{Speciation and Quantification of VOCs Using GC-IMS}

A headspace-gas chromatography-ion mobility spectrometry (HS-GC-IMS) instrument (FlavorSpec ${ }^{\circledR}$ H1-00053, Gesellschaft für Analytische Sensorsysteme mbH (G.A.S.), Dortmund, Germany) was used to analyze the VOCs. The analysis was carried out at the G.A.S. Department of the Shandong HaiNeng Science Instrument Co., Ltd. (Shandong, China). 
Chromatographic separation was performed with an FS-SE-54CB-1 capillary column (15 m, ID: $0.53 \mathrm{~mm}$ ), a radioactive ionization source (tritium; $6.5 \mathrm{KeV}$ ), and a heated splitless injector for direct automatic sampling of headspace volatile compounds from the samples into the GC-IMS instrument.

Prior to the GC-IMS analysis, the sample $(1 \mathrm{~g})$ was heated at $80^{\circ} \mathrm{C}$ for $20 \mathrm{~min}$ in an incubating box to generate volatile compounds. The injection volume was set to $500 \mu \mathrm{l}$, the injection speed was $0.6 \mathrm{ml} \mathrm{s}^{-1}$, and the injector temperature was $80^{\circ} \mathrm{C}$. The temperature of the automatic headspace sampler was set to $85^{\circ} \mathrm{C}$ for $15 \mathrm{~min}$. After sample injection, the VOCs were pushed into the multicapillary column via the carrier gas for timely separation. Chromatographic separation was executed at $60^{\circ} \mathrm{C}$ : the carrier gas flow rate was initially set at $2 \mathrm{ml} \mathrm{min}^{-1}$ for $2 \mathrm{~min}$; the flow was linearly increased to $15 \mathrm{ml} \mathrm{min}^{-1}$ over $8 \mathrm{~min}$; it was further increased to $80 \mathrm{ml} \mathrm{min}^{-1}$ over $10 \mathrm{~min}$; and finally, the flow reached $150 \mathrm{ml} \mathrm{min}{ }^{-1}$ over $5 \mathrm{~min}$. The total run time lasted for $40 \mathrm{~min}$ in order to achieve a better separation effect.

After the separation in the capillary column at $60^{\circ} \mathrm{C}$, the headspace was pushed into the ionization chamber for prior ionization, then driven into the drift region through a shutter grid, and finally passed into the IMS detector. The operating conditions of the IMS are as follows: the drift tube length was $5 \mathrm{~cm}$ and operated at a constant voltage of $400 \mathrm{~V} \mathrm{~cm}^{-1}$; and the temperature of the drift tube was $45^{\circ} \mathrm{C}$ with nitrogen (99.999\% in purity) flow rate of $150 \mathrm{ml} \mathrm{min}^{-1}$. Each sample was analyzed twice by GC-IMS. The results are expressed as the average value to reduce unintentional errors.

\section{X-Ray Powder Diffraction Analysis}

The mineral composition of sediments was determined through the XRD analysis using an X'Pert-PRO diffractometer with CuKa radiation source having a scanning speed of $0.02 \%$. The voltage and tube currents were $45 \mathrm{kV}$ and $30 \mathrm{~mA}$, respectively.

The XRD analysis was carried out at the Qinghai Institute of Salt Lake, Chinese Academy of Sciences (Xining, China).

\section{n-Alkane Analysis}

The salt lake sediments were extracted using an accelerated solvent extractor (Dionex ASE 350) with dichloromethane/ methanol (93:7) at $100^{\circ} \mathrm{C}$ and 1,600 psi for two cycles. The $n$-alkane was separated using a deactivated silica gel column eluted with $n$-hexane. The concentration of $n$-alkanes was quantified using the GC-MS system (7890B/5977B, Agilent technologies). The capillary column was an HP-5MS silica capillary column $(30 \mathrm{~m} \times 250 \mu \mathrm{m} \times 0.25 \mu \mathrm{m})$, coated with $5 \%$ phenyl methyl silox. The GC-oven temperature was started at $50^{\circ} \mathrm{C}$ (held for $1 \mathrm{~min}$ ) and then to $315^{\circ} \mathrm{C}$ (held for $16 \mathrm{~min}$ ) at $8^{\circ} \mathrm{C} /$ min. The individual $n$-alkanes were identified and quantified by comparing with the spectra obtained after running Fluka alkanemixture standard $\left(\mathrm{C}_{10}-\mathrm{C}_{40}\right)$.

The carbon preference index (CPI) (Marzi et al., 1993) value was calculated using the following equations:

$\mathrm{CPI}=\frac{\left(C_{23}+C_{25}+C_{27}+C_{29}+C_{31}\right)+\left(C_{25}+C_{27}+C_{29}+C_{31}+C_{33}\right)}{2 \times\left(C_{24}+C_{26}+C_{28}+C_{30}+C_{32}\right)}$

\section{Data Processing}

First, the proportion of VOCs in the total OM was quantified. Then, the VOCs among different samples were measured using GC-IMS and processed using LAV-Gallery Plot 2.2.0 (G.A.S., Germany) software. LAV was used to view the analysis spectrum, where each point represented a VOC. Signal intensity was indicated by the color and could be used as a quantitative analysis tool. The background of the plot was blue, while the red line on the left on the plot indicated the reactive ion peak (RIP; normalized drift time, $-7.81 \mathrm{~ms}$ ). Each point on the plot represented a different VOC, with the concentration of each point indicated by the color, as follows: white, lower concentration; yellow, low concentration; red, high concentration; and a darker color indicates a higher concentration.

Next, XRD analysis was conducted, and Q-cluster analysis was performed by using the content of VOCs to study the relationship between samples. Cluster analysis, a multivariate statistical method that is widely used in geology, was derived according to the principles of dimension reduction (Eskanazy et al., 2010; Gazley et al., 2015). The Q-cluster analysis is defined as the classification of similar objects into groups, in which the number of groups and their forms is unknown (Gentle et al., 1991). The primary purpose of Q-cluster analysis is to statistically measure the degree of similarity between samples and then aggregate samples with a high degree of similarity into one class. Further, the relationship between the distribution of VOCs and mineral content was investigated herein. Finally, the main sources of $\mathrm{OM}$ and factors affecting the distribution of VOC were determined by n-alkane analysis.

\section{RESULTS}

\section{The Proportion of Volatile Organic Compounds}

The contents of TOC and VOCs in the lake sediment samples are presented in Table 1. Differences were observed in the samples from various types of lake sediments. The TOCs values ranged from 0.15 to $1.22 \%$; specifically, the TOC content of clay ranged from 0.5 to $1.22 \%$ (avg $0.81 \%$ ), while that of sandstone and halite ranged from 0.15 to $0.26 \%$ (avg $0.22 \%$ ). The VOC values ranged from 0.01 to $0.06 \%$; specifically, and the VOC content of clay ranged from 0.01 to $0.06 \%$ (avg $0.02 \%$ ), while that of sandstone and halite ranged from 0.01 to $0.02 \%$ (avg $0.02 \%$ ). This observation is quite different from the findings of Bianchi et al. (1991), who reported that the values of VOCs identified by GC-MS in Southampton's estuarine sediments ranged from $<0.01$ to $0.28 \%$ (avg $0.14 \%$ ). This difference may be attributed to the differences in the environment during the formation of estuarine and salt lake sediments. The proportion of VOCs in TOC ranged from 1.14 to $13.33 \%$; specifically, the proportion in clay ranged from 1.14 to $4.92 \%$ (avg $2.83 \%$ ), while that in sandstone and halite ranged from 5.00 to $13.33 \%$ (avg $8.54 \%$ ). 
TABLE 1 | Total organic carbon, volatile organic compounds ratio, and mineral composition in the samples.

\begin{tabular}{|c|c|c|c|c|c|c|c|c|c|c|c|c|c|}
\hline \multirow[t]{2}{*}{ No. } & TOC $_{\mathrm{s}}$ & TOC $_{\mathrm{d}}$ & $\omega_{\text {voc }}$ & Qu & So & Mu & Gy & $\mathrm{Ca}$ & Do & Ar & Sy & Ch & $\mathrm{Ha}$ \\
\hline & \multicolumn{13}{|c|}{$\%$} \\
\hline DT01 & 0.50 & 0.49 & 2.00 & 28 & 10 & 32 & 1 & 4 & nd & 7 & nd & 9 & 9 \\
\hline DT02 & 0.88 & 0.87 & 1.14 & 16 & 8 & 28 & 6 & 2 & nd & nd & nd & 10 & 30 \\
\hline DT03 & 0.74 & 0.73 & 1.35 & 29 & 12 & 32 & 5 & 4 & 2 & nd & nd & 11 & 5 \\
\hline DT04 & 1.08 & 1.05 & 2.78 & 24 & 15 & 21 & 25 & 2 & nd & nd & nd & 7 & 6 \\
\hline DT05 & 0.70 & 0.67 & 4.29 & 25 & 16 & 34 & nd & 6 & nd & nd & nd & 12 & 7 \\
\hline DT06 & 0.80 & 0.78 & 2.50 & 25 & 18 & 24 & 15 & 7 & nd & nd & nd & 7 & 4 \\
\hline DT07 & 1.22 & 1.16 & 4.92 & 30 & 23 & 26 & nd & 6 & nd & nd & nd & 9 & 6 \\
\hline DT08 & 0.24 & 0.22 & 8.33 & 24 & 21 & 32 & nd & 6 & nd & nd & nd & 10 & 7 \\
\hline DT09 & 0.15 & 0.13 & 13.33 & 2 & nd & nd & 28 & nd & nd & nd & nd & nd & 70 \\
\hline DT010 & 0.20 & 0.19 & 5.00 & 4 & 9 & nd & 23 & nd & nd & nd & nd & nd & 64 \\
\hline DT011 & 0.26 & 0.24 & 7.69 & 4 & nd & nd & nd & nd & nd & nd & nd & nd & 96 \\
\hline DT012 & 0.24 & 0.22 & 8.33 & 8 & nd & 17 & 60 & nd & nd & nd & nd & nd & 15 \\
\hline DT013 & $\mathrm{TOC}_{\mathrm{s}}$ & $\mathrm{TOC}_{\mathrm{d}}$ & $\omega_{\mathrm{VOC}}$ & 4 & nd & nd & 7 & nd & nd & nd & 5 & nd & 84 \\
\hline
\end{tabular}

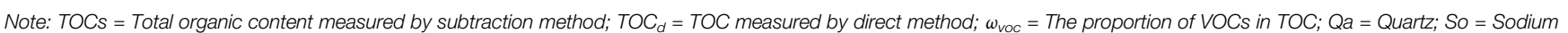
feldspar; $\mathrm{Mu}=$ Muscovite; Gy = Gypsum; Ca = Calcite; Do = Dolomite; Ar = Aragonite; Sy = Sylvite; Ch = Chlorite; Ha = Halite; $n d=$ not detected.

\section{Volatile Organic Compounds' Speciation as Revealed by GC-IMS}

In the present study, GC-IMS was employed to analyze the VOCs in various lake sediments of different sedimentary environments in East Taijinar salt lake. A three-dimensional (3D) spectrum was drawn using the FlavorSpec ${ }^{\circledR}$ instrument. Figure 2 displays the difference in the matrix plot of the GC-IMS spectra. Results show that the peak intensities of volatile components in the different samples varied.

Based on the duration of the measurement run and the normalized drift time, the $2 \mathrm{D}$ spectrum, a supplement to the $3 \mathrm{D}$ spectrum, was obtained (Figure 3 ). The points in the $2 \mathrm{D}$ spectrum correspond to the peaks in the $3 \mathrm{D}$ spectrum, which can reflect the number of compounds identified clearly. The volatile substances in the different strata behaved differently with respect to their signal intensities (Figure 3).

A total of 34 typical compounds were identified using the GC-IMS Library, excluding six contaminants (octamethylcyclotetrasiloxane D, octamethylcyclotetrasiloxane $\mathrm{M}$, decamethylcyclopentasiloxane $\mathrm{D}$, decamethylcyclopentasiloxane $\mathrm{M}$, hexamethylcyclotrisiloxane, and 2-ethyl-1-hexanol). The details of the identified compounds (40 peaks, 34 compounds), including the chemical names, Chemical Abstracts Service (CAS) numbers, molecular formula, retention index (RI), retention time, and migration time, are listed in Table 2. The 34 substances, apart from five silicone substances and 2-ethyl-1-hexanol, as mentioned before, were classified into seven types, including terpenes, furan, esters, aldehydes, ketones, alcohols, and acids. Several compounds, including 2-butanone, hexanal, ethyl pentanoate, 2-pinene, benzaldehyde, octamethylcyclotetrasiloxane, n-nonanal, and decamethylcyclopentasiloxane produced different product ions and showed two peaks, corresponding to monomers and dimers; and are attributed to their varying concentrations ( $\mathrm{Li}$ et al., 2019). These products featured different drift times but similar retention times. During the drift time, more than one signal was observed for a single compound due to the formation of adducts between the analyzed ions and the neutral molecules as they moved through the drift region (Rodríguez-Maecker et al., 2017). High proton affinity or a higher analyte concentration may lead to the formation of dimers (Lantsuzskaya et al., 2015).

The 2D spectrum (Figure 3) indicates that the three types of salt lake sediments were distinctly different, and the concentration of most VOCs in clay (Figure 3A) was higher than that in sandstone (Figure 3B) and halite (Figure 3C). In order to compare the differences among these samples, different compounds were numbered on the map, and for intuitive viewing, an area set was created that integrated all labeled peaks (Figure 4). The most evident difference among the three samples was the presence of a siloxane substance, which was numbered as 14, 31-32, and 38-39 (shown in the red frame and the yellow dotted frame of Figure 4). However, most of these substances did not originate from the sample itself; instead, they existed in the stationary phases of the chromatographic column (Levin and Lantsuzskaya, 2014) and could not be avoided when testing. Moreover, the reagent used for boron extraction from the East Taijinar salt lake brine was 2-ethyl-1-hexanol (Gao et al., 2010), which was identified during the analysis. Therefore, this compound was considered an anthropic pollutant.

A more precise comparison is provided in Figures 4, 5, which present all the identified substances. In particular, the values of concentration of the identified compounds numbered as $1-5,7,9$, $11-12,15,17-21,23,25-26,28,30,34,36-37$, and 40 (shown in the red dotted frame of Figure 4) were found to be higher in the clay samples.

\section{Mineralogy}

$\mathrm{XRD}$ analysis indicates that the sediments comprised detrital mineral, carbonate, sulfate, silicate, and halite (Table 1). The detrital minerals consisted of quartz, sodium feldspar, and muscovite. Muscovite was the most dominant detrital mineral (up to $32 \%$ ), followed by quartz and sodium feldspar. The quartz content ranged between 2 and $30 \%$ along the depth profile, whereas sodium feldspar and muscovite were mainly present in the clay, with a low occurrence in the sandstone and halite.

The mineral assemblage other than detrital minerals consisted of carbonate (calcite, dolomite, and aragonite), sulfate (gypsum), 

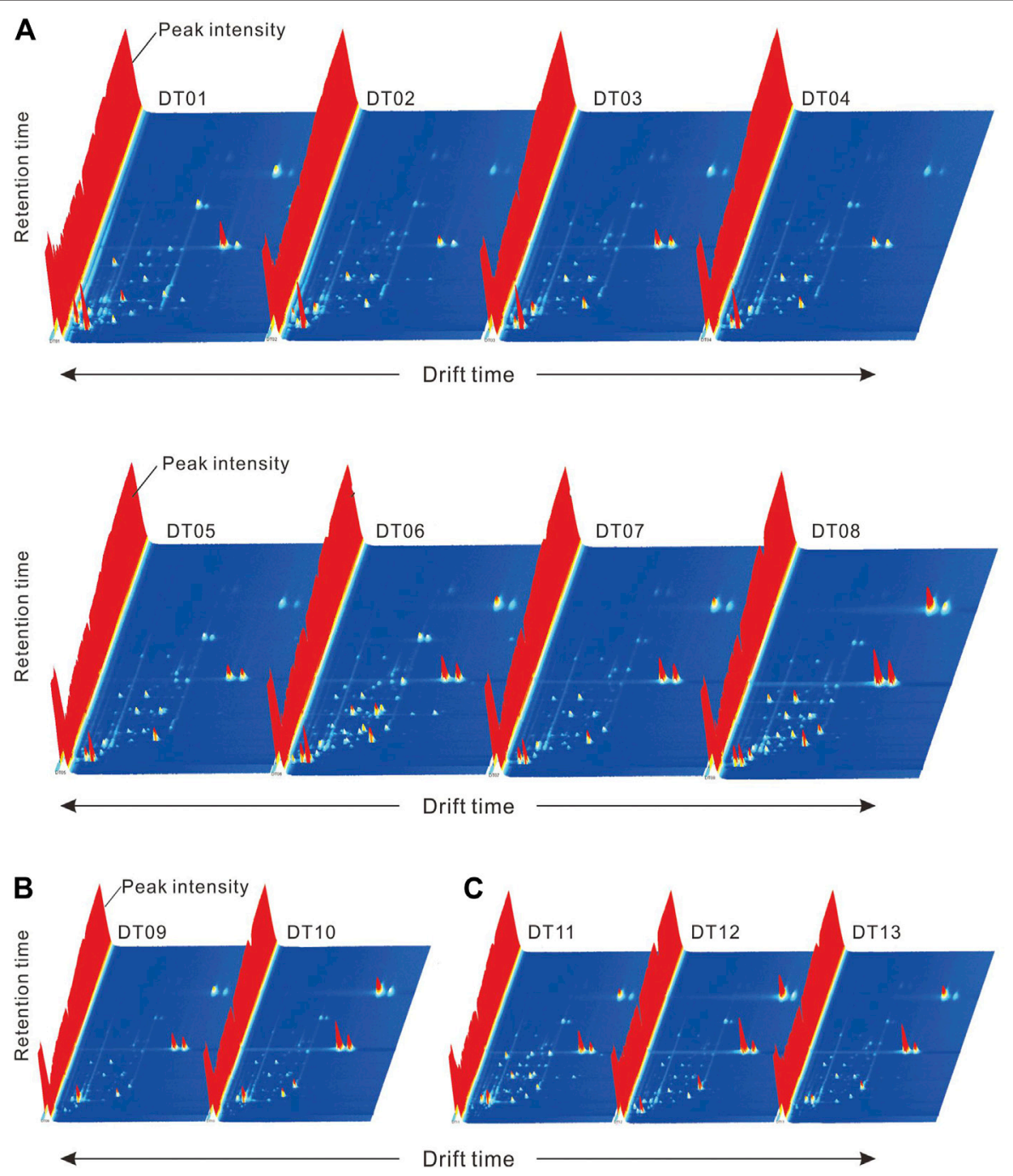

FIGURE 2 | Three-dimensional topographical plots of GC-IMS for different samples: (A): clay (DT01-DT08); (B): sandstone (DT09-DT10); and (C): halite (DT11-DT13).

silicate (chlorite), sylvite, and halite. Carbonate and silicate were only present in the clay, while the content of halite fluctuated between 4 and $96 \%$ along the profile. Sylvite was detected only in halite sediments, and gypsum was identified in all types of sediments.

\section{Q-Cluster Analysis}

In this study, the thirteen samples were divided into two groups using squared Euclidean as the similarity distance and Ward's clustering method as the amalgamation rule. A dendrogram of the Q-cluster analysis method is shown in Figure 6, indicating the identification of two groups: Group I consisted of DT01-DT08 and DT12, while Group II included DT09-DT11 and DT13.

\section{n-Alkanes in Sediments}

$n$-Alkanes with carbon numbers from $\mathrm{C}_{15}$ to $\mathrm{C}_{36}$ were found in all samples. Short-chain $n$-alkanes $\left(\mathrm{C}_{15}-\mathrm{C}_{20}\right)$ were less abundant and varied from 0.97 to $8.61 \%$, with an average of $3.98 \%$. The mid-chain $n$-alkanes $\left(C_{21}-C_{25}\right)$ varied from 5.33 to $35.99 \%$ (avg 19.71\%). The long-chain $n$-alkanes $\left(\mathrm{C}_{26}-\mathrm{C}_{36}\right)$ were exceptionally abundant in all sediments, ranging from 53.25 to $93.19 \%$, with an average of $73.18 \%$. In most cases, $\mathrm{C}_{\max }$ of the long-chain $n$-alkanes fraction was recorded at $\mathrm{C}_{31}$ and $\mathrm{C}_{27}$. For the mid-chain $n$-alkanes, $\mathrm{C}_{\max }$ occurred at $\mathrm{C}_{25}$ only in DP13 (Figure 7). The CPI values in sediments varied from 1.2 to 14.2 (avg 7.2). The $\mathrm{Pr} / \mathrm{Ph}$ values varied from 0.25 to 0.83 (avg 0.48). The $\mathrm{Pr} / \mathrm{nC}_{17}$ and $\mathrm{Pr} / \mathrm{nC}_{18}$ values were relatively large and varied from 0.82 to 2.16 (avg 1.37) and 0.81-1.87 (avg 1.22) (Figure 8), respectively.

\section{DISCUSSION}

\section{The Important Role of Volatile Organic Compounds in Total Organic Carbon}

VOCs account for a small portion of OM in nature; however, they play an important role in the atmosphere (Kesselmeier et al., 2000), food (Xu et al., 2010), water (Ellis and Rivett, 2007), and 


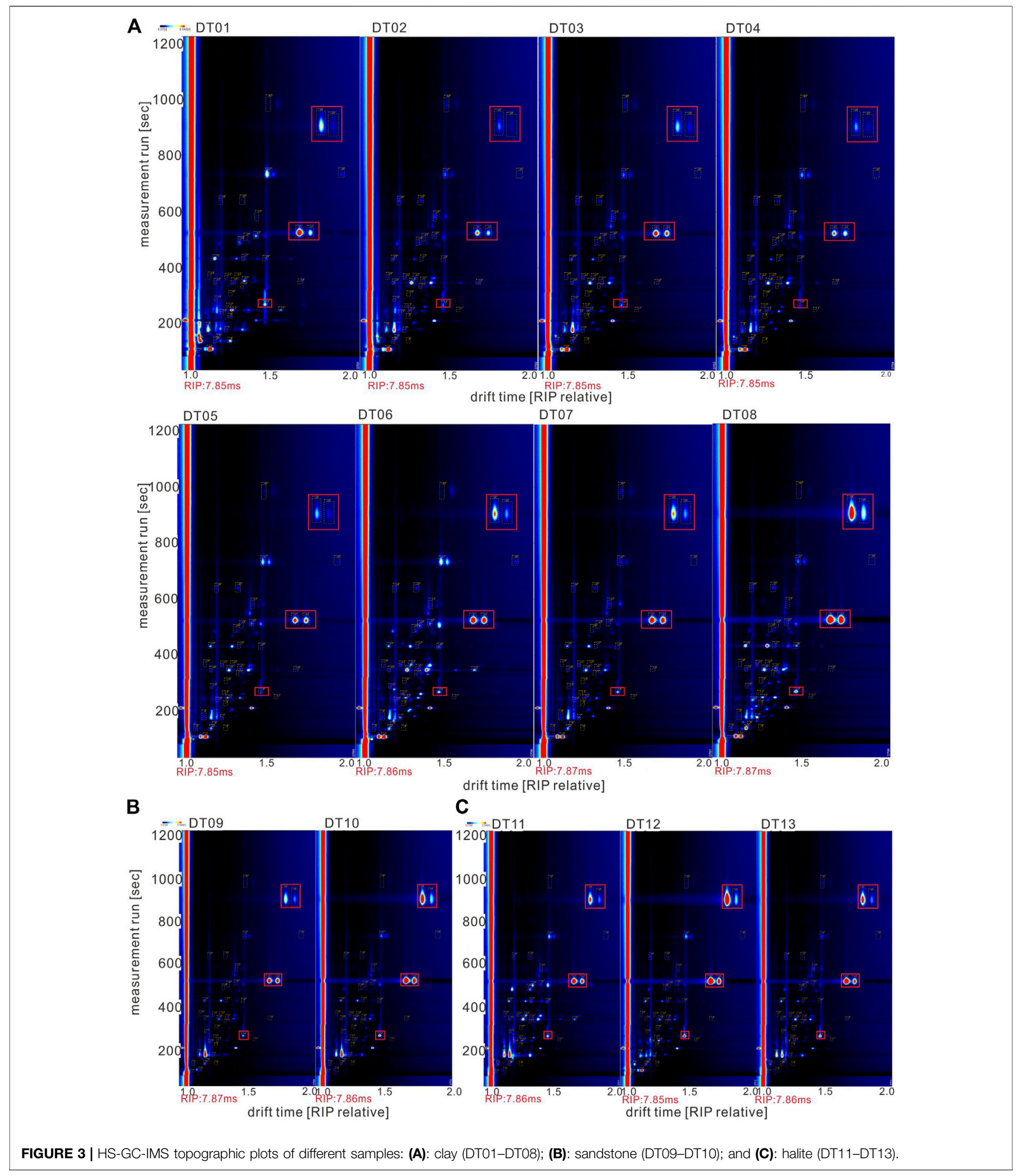


TABLE 2 | Details of the 34 volatile organic compounds detected in the sediment samples.

\begin{tabular}{|c|c|c|c|c|c|c|}
\hline Count & Compound & CAS\# & Formula & $\mathbf{R I}$ & Rt [sec] & Dt [RIPrel] \\
\hline 1 & Methanethiol & C74931 & $\mathrm{CH}_{4} \mathrm{~S}$ & 447 & 100 & 1.045 \\
\hline 2 & Acetone & C67641 & $\mathrm{CH}_{3} \mathrm{COCH}_{3}$ & 488 & 109 & 1.116 \\
\hline 3 & 2-Butanone M & C64197 & $\mathrm{C}_{4} \mathrm{H}_{8} \mathrm{O}$ & 590 & 137 & 1.058 \\
\hline 4 & 2-Butanone D & C78933 & $\mathrm{C}_{4} \mathrm{H}_{8} \mathrm{O}$ & 591 & 138 & 1.245 \\
\hline 5 & Acetic acid & C78933 & $\mathrm{CH}_{3} \mathrm{COOH}$ & 591 & 138 & 1.152 \\
\hline 6 & 2,3-Butanedione & C431038 & $\mathrm{C}_{4} \mathrm{H}_{6} \mathrm{O}_{2}$ & 624 & 150 & 1.169 \\
\hline 7 & 2,3-Pentanedione & C600146 & $\mathrm{C}_{5} \mathrm{H}_{8} \mathrm{O}_{2}$ & 683 & 176 & 1.221 \\
\hline 8 & Propanoic acid & C79094 & $\mathrm{CH}_{3} \mathrm{CH}_{2} \mathrm{COOH}$ & 696 & 183 & 1.109 \\
\hline 9 & 3-Methyl-3-buten-1-ol & C763326 & $\mathrm{C}_{5} \mathrm{H}_{10} \mathrm{O}$ & 765 & 225 & 1.245 \\
\hline 10 & Ethyl-2-methylpropanoate & C97621 & $\mathrm{C}_{6} \mathrm{H}_{12} \mathrm{O}_{2}$ & 784 & 239 & 1.193 \\
\hline 11 & Hexanal D & C66251 & $\mathrm{C}_{6} \mathrm{H}_{12} \mathrm{O}$ & 796 & 249 & 1.558 \\
\hline 12 & Hexanal M & C66251 & $\mathrm{C}_{6} \mathrm{H}_{12} \mathrm{O}$ & 796 & 248 & 1.256 \\
\hline 13 & Acetic acid butyl ester & C123864 & $\mathrm{C}_{6} \mathrm{H}_{12} \mathrm{O}_{2}$ & 813 & 262 & 1.234 \\
\hline 14 & hexamethylcyclotrisiloxane ${ }^{*}$ & C541059 & $\mathrm{C}_{6} \mathrm{H}_{18} \mathrm{O}_{3} \mathrm{Si}_{3}$ & 821 & 269 & 1.464 \\
\hline 15 & Butanoic acid & C107926 & $\mathrm{C}_{4} \mathrm{H}_{8} \mathrm{O}_{2}$ & 840 & 286 & 1.158 \\
\hline 16 & Ethyl-3-methylbutyrate & C108645 & $\mathrm{C}_{7} \mathrm{H}_{14} \mathrm{O}_{3}$ & 859 & 305 & 1.248 \\
\hline 17 & 1-Hexanol & C111273 & $\mathrm{C}_{6} \mathrm{H}_{1} 4 \mathrm{O}$ & 885 & 333 & 1.32 \\
\hline 18 & Ethyl pentanoate D & C539822 & $\mathrm{C}_{7} \mathrm{H}_{14} \mathrm{O}_{2}$ & 897 & 347 & 1.684 \\
\hline 19 & Ethyl pentanoate M & C539822 & $\mathrm{C}_{7} \mathrm{H}_{14} \mathrm{O}_{2}$ & 897 & 348 & 1.264 \\
\hline 20 & Cyclohexanone & C108941 & $\mathrm{C}_{6} \mathrm{H}_{10} \mathrm{O}$ & 897 & 347 & 1.153 \\
\hline 21 & Heptanal & C111717 & $\mathrm{C}_{7} \mathrm{H}_{14} \mathrm{O}$ & 902 & 353 & 1.334 \\
\hline 22 & 2-Pinene D & C80568 & $\mathrm{C}_{42} \mathrm{H}_{24} \mathrm{O}_{14}$ & 912 & 366 & 1.287 \\
\hline 23 & 2-Pinene M & C80568 & $\mathrm{C}_{10} \mathrm{H}_{16}$ & 912 & 366 & 1.221 \\
\hline 24 & 2-Acetylfuran & C1192627 & $\mathrm{C}_{6} \mathrm{H}_{6} \mathrm{O}_{2}$ & 913 & 367 & 1.116 \\
\hline 25 & Benzaldehyde D & C100527 & $\mathrm{C}_{7} \mathrm{H}_{6} \mathrm{O}$ & 957 & 429 & 1.463 \\
\hline 26 & Benzaldehyde M & C100527 & $\mathrm{C}_{7} \mathrm{H}_{6} \mathrm{O}$ & 959 & 432 & 1.148 \\
\hline 27 & 2-Octanone & C111137 & $\mathrm{C}_{8} \mathrm{H}_{16} \mathrm{O}$ & 959 & 432 & 1.328 \\
\hline 28 & Hexanoic acid & C142621 & $\mathrm{C}_{6} \mathrm{H}_{12} \mathrm{O}_{2}$ & 995 & 492 & 1.303 \\
\hline 29 & Ethyl hexanoate & C123660 & $\mathrm{C}_{8} \mathrm{H}_{16} \mathrm{O}_{2}$ & 1,003 & 506 & 1.342 \\
\hline 30 & $n$-hexyl acetate & C142927 & $\mathrm{C}_{8} \mathrm{H}_{16} \mathrm{O}_{2}$ & 1,007 & 512 & 1.406 \\
\hline 31 & Octamethylcyclotetrasiloxane D* & C556672 & $\mathrm{C}_{8} \mathrm{H}_{24} \mathrm{O}_{4} \mathrm{Si}_{4}$ & 1,013 & 525 & 1.745 \\
\hline 32 & Octamethylcyclotetrasiloxane $\mathrm{M}^{*}$ & C556672 & $\mathrm{C}_{8} \mathrm{H}_{24} \mathrm{O}_{4} \mathrm{Si}_{4}$ & 1,014 & 526 & 1.677 \\
\hline 33 & 2-Ethyl-1-hexanol* & C104767 & $\mathrm{C}_{8} \mathrm{H}_{18} \mathrm{O}$ & 1,041 & 582 & 1.412 \\
\hline 34 & e-2-octenal & C98862 & $\mathrm{C}_{8} \mathrm{H}_{14} \mathrm{O}$ & 1,066 & 638 & 1.322 \\
\hline 35 & Acetophenone & C2548870 & $\mathrm{C}_{8} \mathrm{H}_{8} \mathrm{O}$ & 1,066 & 637 & 1.187 \\
\hline 36 & n-nonanal M & C124196 & $\mathrm{C}_{9} \mathrm{H}_{18} \mathrm{O}$ & 1,103 & 733 & 1.478 \\
\hline 37 & $n$-nonanal D & C124196 & $\mathrm{C}_{9} \mathrm{H}_{18} \mathrm{O}$ & 1,104 & 735 & 1.94 \\
\hline 38 & Decamethylcyclopentasiloxane $D^{\star}$ & C541026 & $\mathrm{C}_{10} \mathrm{H}_{30} \mathrm{O}_{5} \mathrm{Si}_{5}$ & 1,160 & 909 & 1.891 \\
\hline 39 & Decamethylcyclopentasiloxane $\mathrm{M}^{\star}$ & C541026 & $\mathrm{C}_{10} \mathrm{H}_{30} \mathrm{O}_{5} \mathrm{Si}_{5}$ & 1,163 & 916 & 1.812 \\
\hline 40 & Ethyl octanoate & C106321 & $\mathrm{C}_{10} \mathrm{H}_{20} \mathrm{O}_{2}$ & 1,181 & 984 & 1.483 \\
\hline
\end{tabular}

Note: $R I=$ retention index; $R t=$ retention time; $D t=d r i f t$ time; $M=$ monomer; $D=$ dimer; * pollutant.

soil. The VOCs in salt lake sediments significantly influence the microorganisms in the sediments after long-term geological processes (Ding et al., 2020). The consumption of OM by microorganisms also produces VOCs, exhibiting a strong relationship between OM, microorganisms, and VOCs. The VOCs also play an essential role in sediments. Currently, the complexity of salt lake sediments, such as the overall extreme environment (Tazi et al., 2014) with high salinity, has hindered the research on the volatile OM composition of this environment.

In general, since the content of TOC in the salt lake sediments is not high, the influence of VOCs is ignored when studying OM. The commonly used, $\delta^{13} \mathrm{C}$, provides a credible method to characterize the origin of OM preserved in lake sediments (Fry and Sherr, 1989; O'Leary, 1993). However, a large amount of VOCs is lost during pre-experimental treatment (Bisutti et al., 2004); therefore, the results do not reflect the nature and source of VOCs. In this study, the VOC content in TOC was explored using a sophisticated GC-IMS technique, which does not need complicated sample pretreatment. The content of VOCs ranged from 1.14 to $13.33 \%$. The different types of lake sediments vary significantly in their VOC content (Table 1). The VOC proportion in halite was discernably higher than in clay and sandstone, peaking at $13.33 \%$. This finding is partially in agreement with a study showing that the content of some VOCs, such as isoprene, is very high under extreme salinities (Rinnan et al., 2014). Therefore, the loss of VOC will result in inaccurate results when detecting OM in sediments. Thus, the influence of VOCs cannot be ignored when studying $\mathrm{OM}$ in salt lake sediments, especially in halite sediments.

\section{Volatile Organic Compounds Revealed by GC-IMS: Composition and Distribution}

Qualitative analysis of VOCs in the clay, sandstone, and halite samples is presented in Figure 2 and Table 2. A total of 34 typical compounds were identified based on the GC-IMS library. 


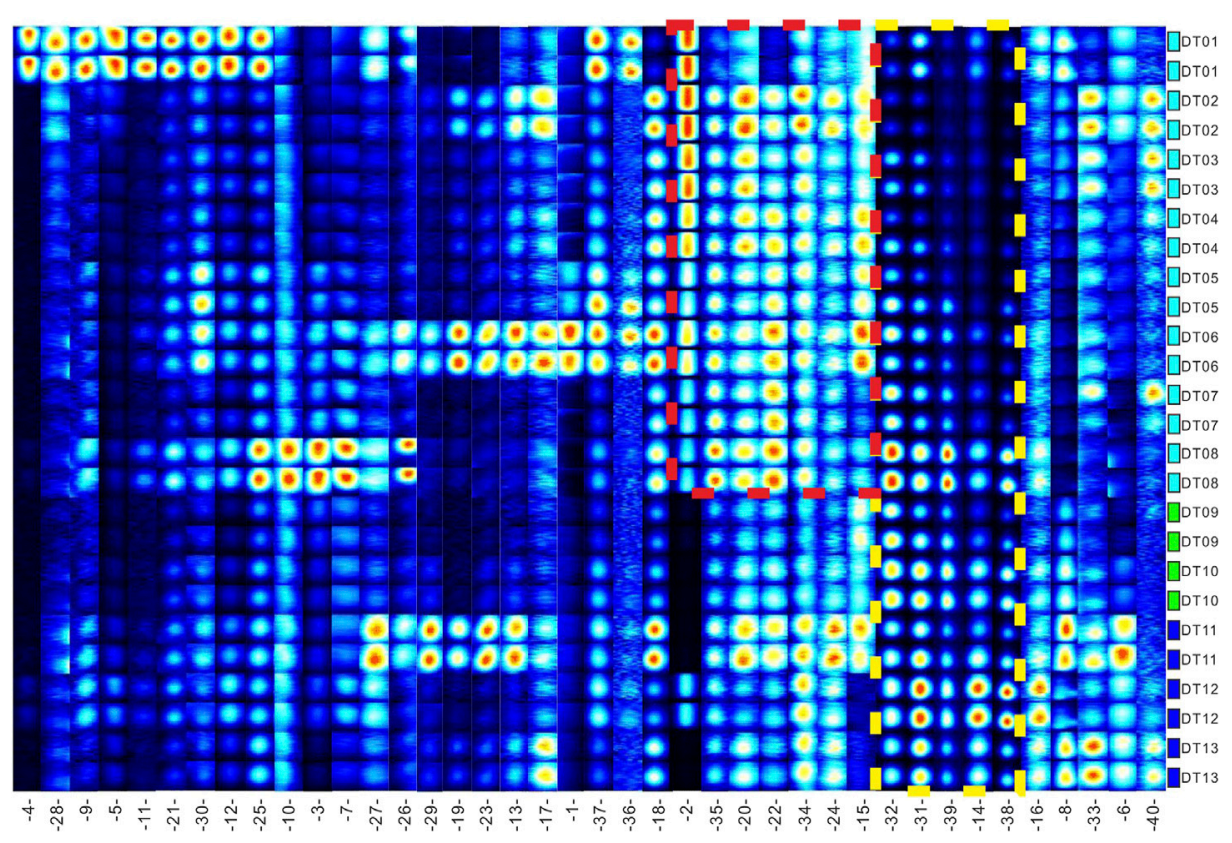

FIGURE 4 | Fingerprints of different sample types in the gallery plot.

In general, the deposition of clay occurs in a relatively mild environment compared with sandstone and halite. Further, clay is rich in microorganisms and bacteria. Previous studies have found that some specific bacteria can degrade dissolved OM to produce more esters, acids, and other substances (Akiyama, 1972). Clay is also known to interact with different types of organic compounds through specific mechanisms. For example, organic molecules can penetrate the interlayer space of clay minerals (Lagaly et al., 2013), preserving the organic compounds in the nanopores of clay minerals during sedimentation (Li et al., 2016). Furthermore, $\mathrm{OM}$ is sometimes adsorbed on the surface of detrital minerals to form aggregates, and a significant positive correlation between the vertical distribution of plankton and the detrital aggregation density has been reported (Buscemi and Puffer, 1975).

Figures 5A,B,G exhibit that some organic compounds, including 2-acetylfuran, 2-pinene D, 2-octanone, acetic acid butyl ester, ethyl hexanoate, and propanoic acid; were found at higher concentrations in the sandstone samples than those in the clay and halite sediments. This could be explained by the fact that the pores in the sandstone are relatively larger compared to those in the clay and halite. Thus, these compounds may easily accumulate in the pores. Similarly, ethyl 2-methylpropanoate, ethyl 3-methylbutyrate, 2,3-butanedione, and acetophenone were found in higher concentrations in the halite than in the clay and sandstone (Figures 5C,D,F). Our findings agree with a previous study that identified VOCs, including hexanal, teradecane, acetic acid butyl ester, and 2-methyl-2-hexenoic acid methyl ester, in salt-stressed algal cells using GC-MS analysis (Zuo et al., 2012). Furthermore, this is partially supported by a study showing that halite's higher salinity may affect the enrichment of some organic compounds, such as phenol monomers, alkylaromatics, and carbohydrates, or the depletion of other organic compounds, such as lipids (Strehse et al., 2018).

The higher salinity also results in a stratified water column, creating an anoxic sedimentary environment and inhibiting the proliferation of bacteria (Zhu et al., 2004), thereby reducing the consumption of OM. Klinkhammer and Lambert (1989) presented evidence for organic carbon preservation in higher salinity sediments, while Jellison et al. (1996) reported a positive correlation between the accumulation rates of organic carbon and salinity. Overall, these phenomena may be attributed to the characteristics of the given sediment layer, such as porosity, salinity, and even different biological composition. Thus, it is not surprising that the VOC content of various types of lake sediments was notably different.

In a previous study, Song et al. (2011) used GC-MS to identify 44 organic compounds from the Qarhan Salt Lake, including linear alkanes $\left(\mathrm{C}_{9}-\mathrm{C}_{20}\right)$, as well as branched alkanes, alcohols, ketones, esters, and low-molecular weight organic compounds. The detected alcohols, ketones, and esters are similar to the compounds identified in the present study. However, GC-MS could not detect furan, terpene, aldehyde, and acid, indicating that GC-IMS is a good supplement to GC-MS detection.

\section{Volatile Organic Compounds in Various Types of Sediments}

Salt lake is a landlocked body of water with high salinity, which is formed in extreme environment and its ecological environment is relatively special. During the sediment deposition period, the content of $\mathrm{OM}$ is less in salt lake than that in river, freshwater lakes, and 


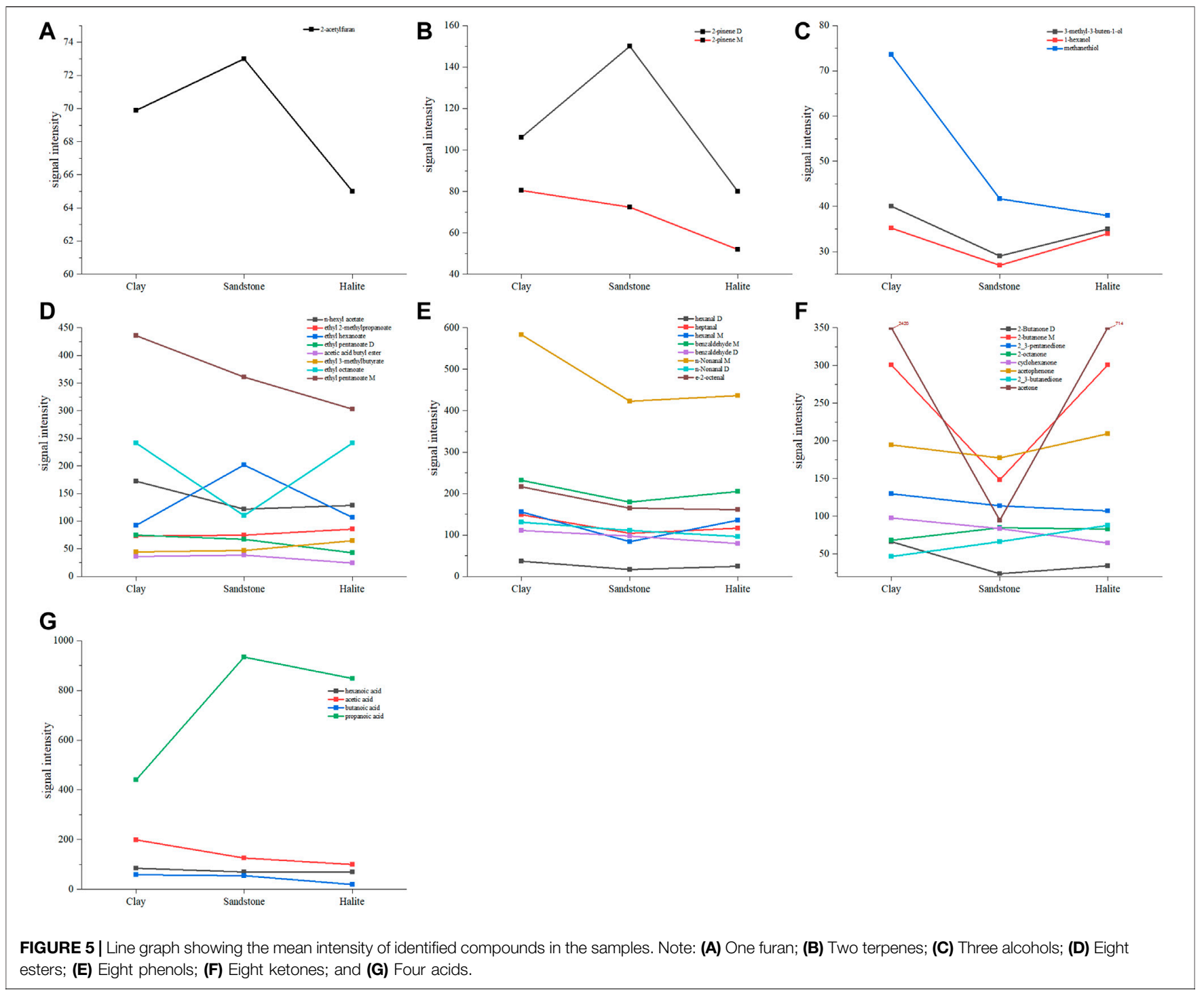

marine sediments. However, owing to the extreme environment produced by some special microorganisms such as halophilic bacteria, some special VOCs such as 3-hydroxybutyrate-co-3hydroxyvalerate are also produced (Thược and Vóc, 2016).

Several studies have been carried out to determine VOCs in various types of sediments. For instance, determination of VOCs in bottom sediments of River Belaya by GC-MS revealed the existence of only hydrocarbons (Galaktionova et al., 2012). A total of 16 VOCs, which could be assigned to aromatic, benzene, alkanes, and olefins was identified and quantified in the samples collected. Susaya et al. (2011) used dynamic flux measurements to identify 12 VOCs in sediment samples collected from various sites of Lake Sihwa, including aldehydes, hydrocarbons, acids, and sulfur compounds. Interestingly, although there was less $\mathrm{OM}$ in salt lake sediments, their species were more abundant than those in freshwater sediments, which could be attributed to special microbial activities in salt lake sediments and the detection sensitivity of equipment. However, 168 VOCs were identified in sediments from Qinghai Lake (Ding et al., 2020) and these were classified into eight types, including acids, phenols, alcohols, ketones, hydrocarbons, aldehydes, esters, and amino acids. Although Qinghai Lake is a brackish lake (salinity $1.3 \%$ ) (Dong et al., 2006), the variety of VOCs in lake sediments was found to be much larger than that in salt lake sediments. This may be attributed to the diversity of Qinghai Lake ecosystem, presence of special animals (ChongYi et al., 2018), plant distribution (Yao et al., 2011), and microbial assemblage (Ren et al., 2017).

Marine sediments cover about $70 \%$ of the Earth's surface (Hoffmann et al., 2020). A wide variety of different types of VOCs, including benzene, toluene, ethyl benzene, and xylene (Han et al., 2007), and sulfur compounds, such as methanethiol (Lomans et al., 2002) has been detected in marine sediments. Bravo-Linares and Mudge (2007) used GC-MS and identified 70 VOCs in sediments obtained from the Menai Strait (salinity 3\%) (Young and Holt, 2007), North Wales, United Kingdom. The 70 


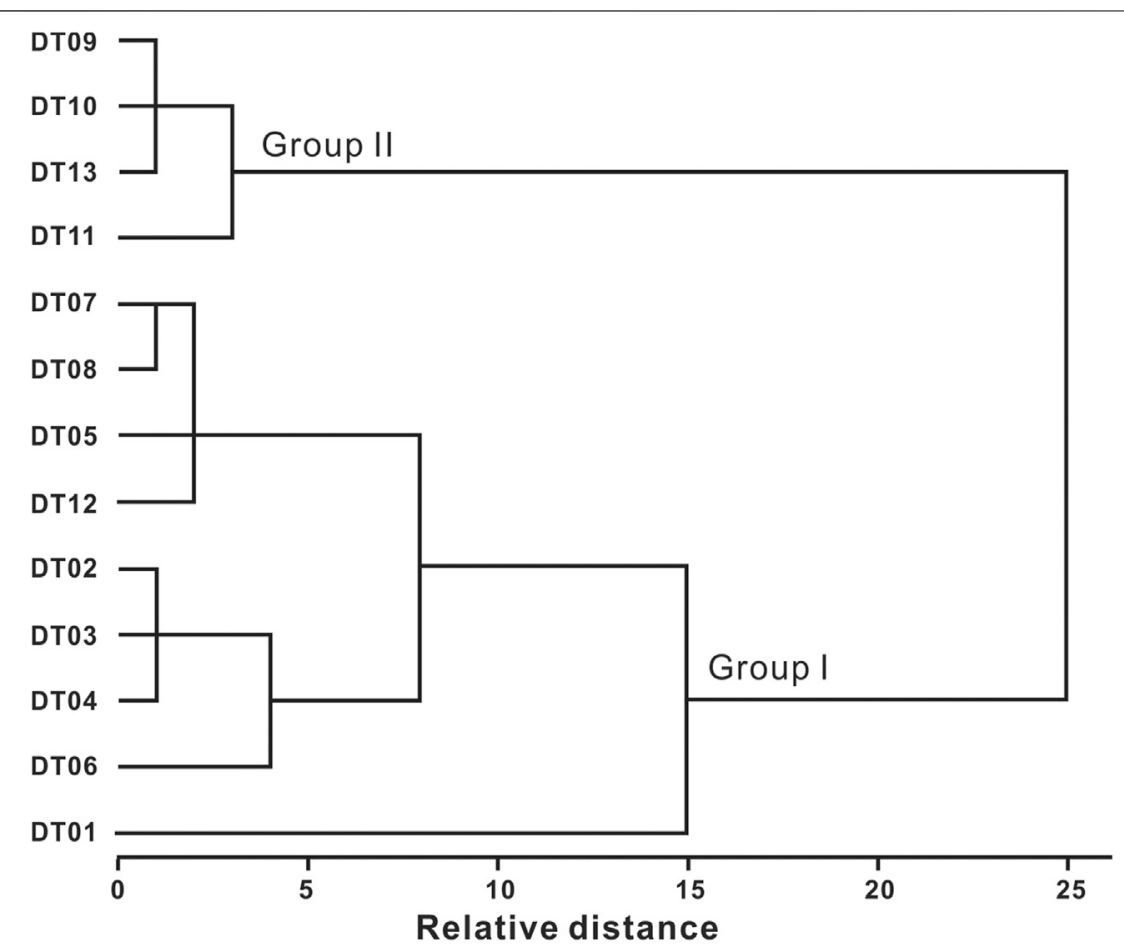

FIGURE 6 | Dendrogram showing the grouping of 13 samples based on the composition of 34 VOCs.

substances were classified into seven types, including hydrocarbons, aldehydes, alcohols, esters, terpenes, sulfides, and halogenated substances. Obviously, the types of VOCs in marine sediments were less than those in Qinghai Lake, but they were more than those in salt lake sediments.

In general, the types of VOCs in saltwater sediments are more abundant than those in freshwater sediments. This may be caused by the special ecosystem and microbial activities in the saltwater lake. However, the types of VOCs in saltwater sediments decrease due to the increase of salinity. This may be attributed to the salinity-induced death of a large number of microorganisms in high-salinity water.

\section{Source Analysis of Organic Matter}

Next, a statistical analysis was conducted in order to explore the distribution of VOCs in salt lake sediments more clearly. A significant difference was observed in the proportion of detrital mineral and halite in the samples, in conjunction with the XRD data. The detrital mineral content in Group I was relatively high $(>25 \%)$, and the halite content was relatively low $(<30 \%)$, while Group II exhibited the opposite characteristics.

The OM constitutes a minor but essential fraction of lake sediments. The OM in lacustrine sediments has two primary sources, i.e., endogenous OM (submerged plants, emergent plants, phytoplankton, and lower bacteria and algae) and exogenous terrestrial OM (terrestrial high plants) (Yang et al.,
2020). Exogenous OM is always associated with mineral grains (Keil et al., 1994), which subsequently slows down its decomposition (Wang and Lee, 1993). Due to its high salinity, endogenous $\mathrm{OM}$ is mainly made up of microorganisms (Han et al., 2020) and algae (Meyers and Ishiwatari, 1993) in salt lake sediments. Detrital minerals are mainly composed of quartz, sodium feldspar, and muscovite. These compounds serve a significant role in the diagenetic process and reflect extrabasinal and intrabasinal sediment input (Zhao et al., 2017a). In general, detrital minerals come from peripheral areas of the lake and are supplied by processes including surface run-off, rivers transport, atmospheric rainfall, and lakeshore erosion (Shen, 2010). In humid climates, the increased precipitation promotes higher surface run-off, carrying the insoluble detrital minerals into the lake and depositing them directly on the bottom of the salt lake. Thus, the content of detrital minerals increases while the salinity is simultaneously reduced.

In this study, the samples were divided into two categories via Q-cluster analysis (Figure 6). In Group I, the content of detrital minerals was relatively high, and the VOCs also exhibited high signal strength. However, the content of detrital minerals in Group II was the lowest. These observations are consistent with the findings of Zhao et al. (2017b), who reported that migrating OM primarily fills the mineral pores of quartz aggregates, likely forming OM networks. Therefore, it can be preliminarily inferred that 


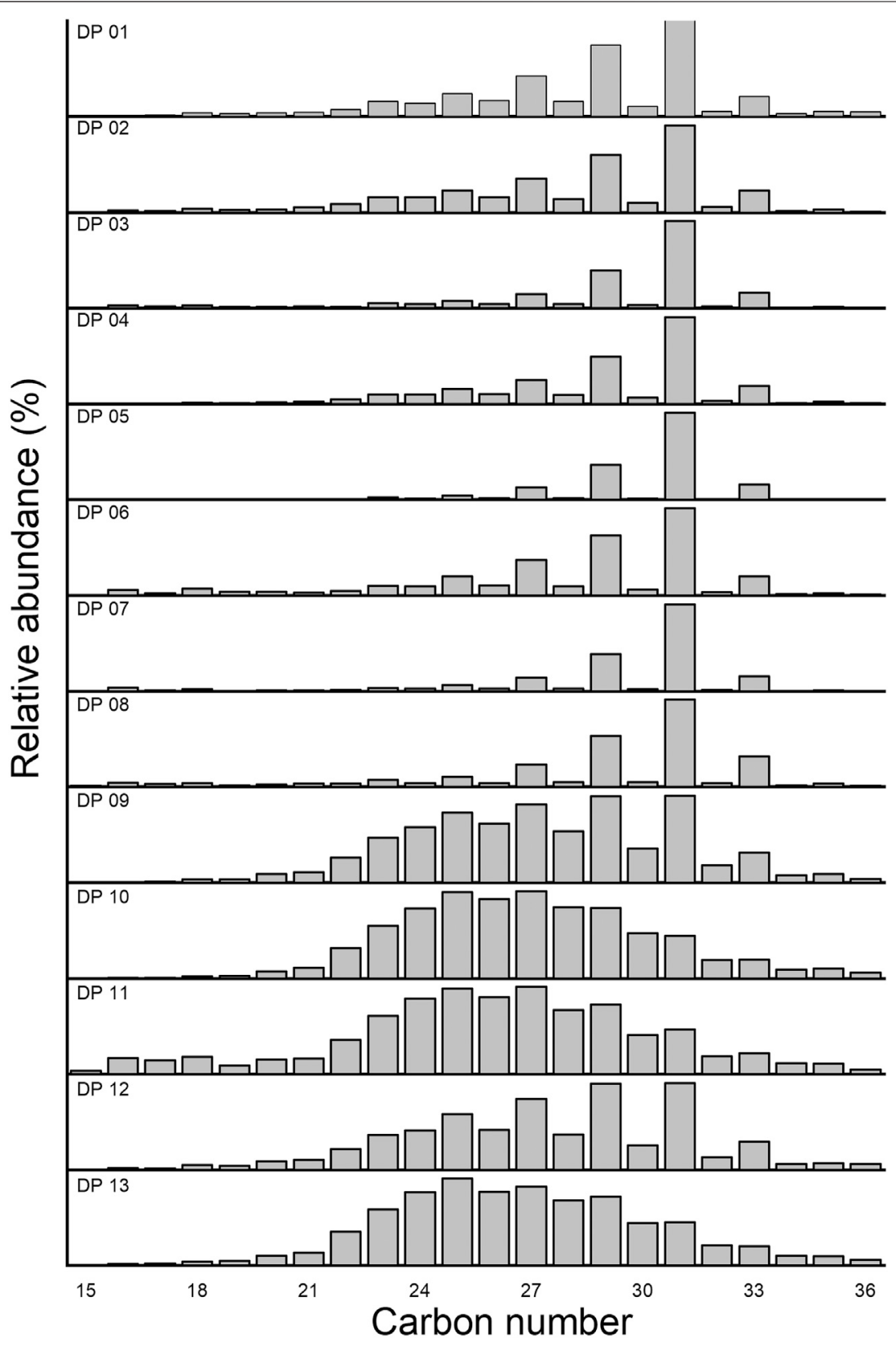

FIGURE 7 | Distributions of n-alkanes in 13 samples from the salt lake sediments.

there are more terrestrial OM and microbial activities in detrital minerals, and the sources of $\mathrm{OM}$ in Group I are mainly exogenous, with a small part coming from endogenous sources. While in Group II, the primary sources of OM were most likely endogenous.

In general, VOCs are important metabolites for microbial cells in different habitats (Ding et al., 2020). They should be mainly controlled by terrestrial or lake algae sourced OM and microbial activities. Therefore, the composition and distribution of VOCs are mainly influenced by terrestrial OM and microbial activities in Group I, and the main source of OM should be terrestrial. On the contrary, the influence of bacteria and algae on VOC in Group
I should be more significant than in Group II. This result was confirmed by $n$-alkane analysis.

\section{Further Verification of the Source of Organic Matter by $n$-Alkanes}

High CPI values in sediments of Group I indicate that the $n$-alkanes in salt sediments originate mainly from higher plants (Cranwell et al., 1987). Bacteria and algae produce short-chain $n$-alkanes without an odd-over-even predominance (Meyers, 2003), whereas the abundance of odd long-chain $n$-alkanes $\left(\mathrm{C}_{27}-\mathrm{C}_{31}\right)$ has been extensively used $\mathrm{e}$ as an 


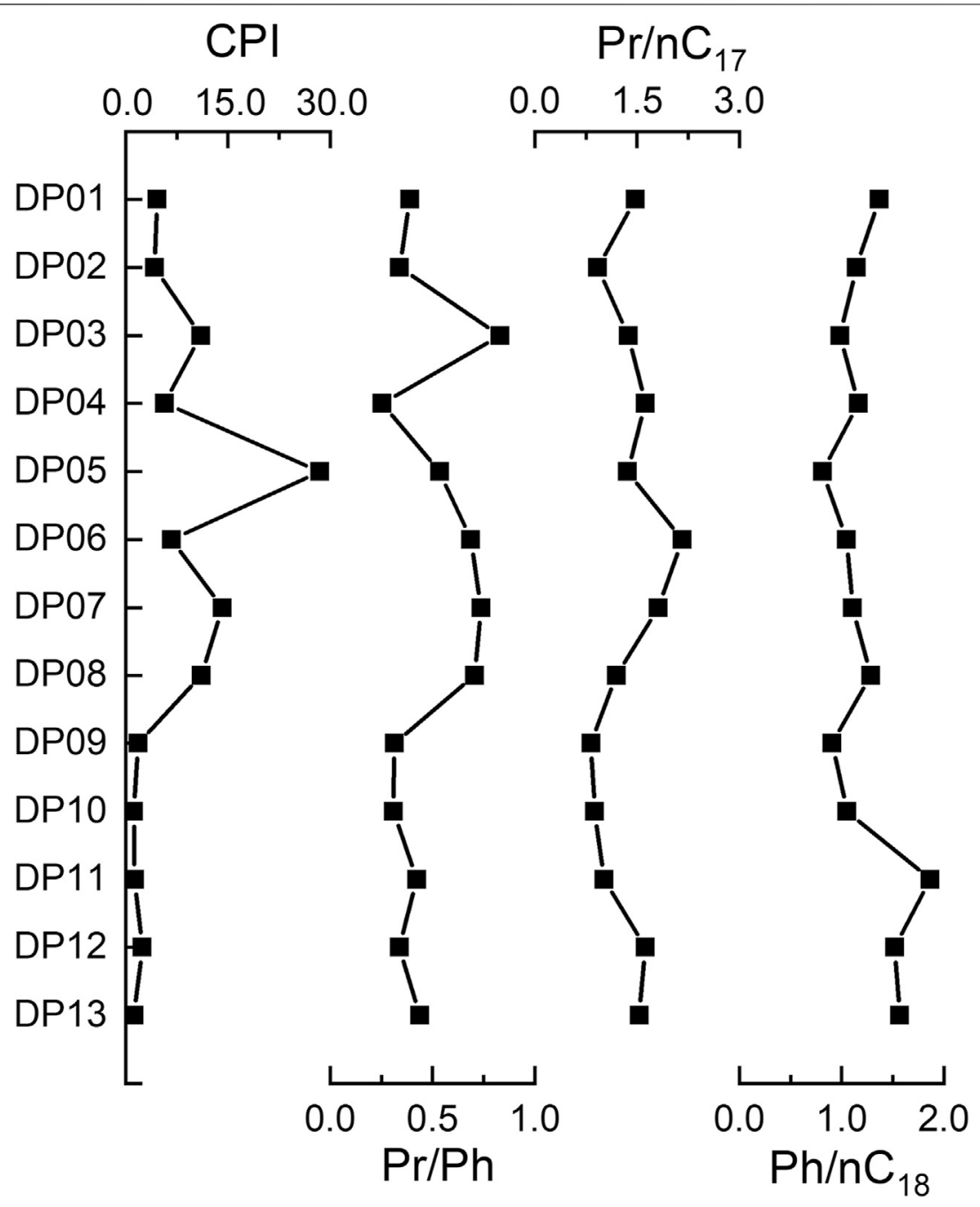

FIGURE 8 | CPI, $\mathrm{Pr} / \mathrm{Ph}, \mathrm{Pr} / \mathrm{nC}_{17}$, and $\mathrm{Pr} / \mathrm{nC}_{18}$ values of 13 samples from the East Taijinar salt lake sediments.

indicator of terrestrial or land-derived OM (Pearson and Eglinton, 2000; Zhao et al., 2003). The samples in salt lake sediments of Group I exhibited an odd-over-even predominance and were mainly dominated by $\mathrm{C}_{31}$. At the same time, the Group II samples were dominated by longchain $n$-alkanes without an odd-over-even predominance. This result is supported by a previous study showing that long-chain $n$-alkanes can also be produced by bacteria and algae, but these long-chain n-alkanes do not have odd-even dominance (Castañeda and Schouten, 2011).

Moreover, values of CPI $>1.0$ indicate terrestrial OM input (Bray and Evans, 1961). The index of CPI in Group I ranged from 2.46 to 14.2 (avg 9.84), demonstrating that the main source of OM should be terrestrial in salt lake sediments. The values of $\mathrm{Pr} / \mathrm{Ph}$, $\mathrm{Pr} / \mathrm{C}_{17}$, and $\mathrm{Pr} / \mathrm{C}_{18}$ are given in Figure 8. $\mathrm{Pr} / \mathrm{Ph}$ ratio is used in a lacustrine setting to infer the oxic vs. anoxic state during $\mathrm{OM}$ deposition. $\mathrm{Pr} / \mathrm{Ph}$ ratios $<1.0$ indicate anoxic conditions, whereas values $>1.0$ reflect suboxic to oxic environments (Didyk et al., 1978). In the East Taijinar salt lake sediments, $\mathrm{Pr} / \mathrm{Ph}$ value suggested an anoxic condition toward the present. The $\mathrm{Pr} /$ $\mathrm{nC}_{17}$ and $\mathrm{Pr} / \mathrm{nC}_{18}$ values of $\mathrm{OM}$ without degradation were very low $(0.1-0.5)$, but they exhibit high values when $\mathrm{OM}$ is affected by microorganisms (Zhao et al., 2016). The ratio of $\mathrm{Pr} /$ $\mathrm{nC}_{17}\left(0.82-2.16\right.$ avg 1.37) and $\mathrm{Pr} / \mathrm{nC}_{18}(0.81-1.87$ avg 1.22) indicate strong microbial activities in East Taijinar salt lake sediments.

In simple terms, the OM in Group I of the East Taijinar salt lake sediments are mainly terrestrial OM, and the source of OM in Group II could be bacteria and algae. Also, the OM in all sediments is strongly affected by microorganisms in anoxic environments. This is consistent with the results of the study on the distribution characteristics of VOC in this paper.

\section{CONCLUSION}

This work preliminarily characterizes the composition and distribution of VOCs in the East Taijinar salt lake sediments. 
VOCs were detected for the first time in salt lake sediments using a state of the art GC-IMS. The high proportion of VOC in TOC implies the halite can better protect VOCs in salt lake sediments. The VOC concentration was significantly different in clay, sandstone, and halite sediments. The types of VOCs in salt lake sediments are more abundant than those in freshwater sediment, but decrease with the increase in the salinity in saltwater lake. The variation in the levels of these volatile compounds could be attributed to lithology, porosity, salinity, and even biological aspects. The Q-cluster analysis and XRD data showed a positive correlation between the distribution of VOC and detrital minerals, indicating that the source of OM in different groups should be different. The analysis of $n$-alkanes indicates that the sources of $\mathrm{OM}$ in the two groups are exogenous and endogenous, respectively, and are strongly affected by microorganisms in an anoxic environment, which confirms that the distribution of VOCs is related to the source of OM and microbial activity.

Undeniably, more systematic explorations are needed to investigate VOCs in the salt lake sediment for gaining a better understanding and acquiring scientific data for salt lake geological studies. Samples from other regions should be incorporated to explore the vital role of VOCs in salt lake evolution.

\section{REFERENCES}

Akiyama, T. (1972). Chemical Composition and Molecular Weight Distribution of Dissolved Organic Matter Produced by Bacterial Degradation of green Algae. Geochem. J. 6, 93-104. doi:10.2343/geochemj.6.93

Amaral, O. C., Olivella, L., Grimalt, J. O., and Albaiges, J. (1994). Combined Solvent Extraction-Purge and Trap Method for the Determination of Volatile Organic Compounds in Sediments. J. Chromatogr. A 675, 177-187. doi:10.1016/00219673(94)85271-5

Armenta, S., Alcala, M., and Blanco, M. (2011). A Review of Recent, Unconventional Applications of Ion Mobility Spectrometry (IMS). Analytica Chim. Acta 703, 114-123. doi:10.1016/j.aca.2011.07.021

Bisutti, I., Hilke, I., and Raessler, M. (2004). Determination of Total Organic Carbon - an Overview of Current Methods. Trac Trends Anal. Chem. 23, 716-726. doi:10.1016/j.trac.2004.09.003

Bravo-Linares, C. M., and Mudge, S. M. (2007). Analysis of Volatile Organic Compounds (VOCs) in Sediments Using In Situ SPME Sampling. J. Environ. Monit. 9 (5), 411-418. doi:10.1039/B617215F

Bray, E. E., and Evans, E. D. (1961). Distribution of N-Paraffins as a Clue to Recognition of Source Beds. Geochimica et Cosmochimica Acta 22, 2-15. doi:10.1016/0016-7037(61)90069-2

Buscemi, P. A., and Puffer, J. H. (1975). Chemico-trophic Attributes of Detrital Aggregates in a New Mexico Alkaline Reservoir. SIL Proc. 1922-2010 19, 358-366. doi:10.1080/03680770.1974.11896075

Castañeda, I. S., and Schouten, S. (2011). A Review of Molecular Organic Proxies for Examining Modern and Ancient Lacustrine Environments. Quat. Sci. Rev. 30, 2851-2891. doi:10.1016/j.quascirev.2011.07.009

Cavanna, D., Zanardi, S., Dall'Asta, C., and Suman, M. (2019). Ion Mobility Spectrometry Coupled to Gas Chromatography: A Rapid Tool to Assess Eggs Freshness. Food Chem. 271, 691-696. doi:10.1016/ j.foodchem.2018.07.204

ChongYi, E., Sun, Y., Liu, X., Hou, G., Lv, S., Yuan, J., et al. (2018). A Comparative Study of Radiocarbon Dating on Terrestrial Organisms and Fish from Qinghai Lake in the Northeastern Tibetan Plateau, China. The Holocene 28 (11), 1712-1719. doi:10.1177/0959683618788671

\section{DATA AVAILABILITY STATEMENT}

The raw data supporting the conclusion of this article will be made available by the authors, without undue reservation.

\section{AUTHOR CONTRIBUTIONS}

ZM, FC, and GZ performed the fieldwork. XL and LY performed laboratory analysis. XL, LY, and ZM prepared Graphics and Tables. XL, ZM, and FH wrote the manuscript with the help of all co-authors.

\section{FUNDING}

This work was supported by the Natural Science Foundation of Qinghai Province (2019-ZJ-911).

\section{ACKNOWLEDGMENTS}

The authors are thankful to ZM for assistance with X-ray powder diffraction. We also acknowledge Lijuan Han for her assistance in the experiment and data analysis.

Cranwell, P. A., Eglinton, G., and Robinson, N. (1987). Lipids of Aquatic Organisms as Potential Contributors to Lacustrine Sediments-II. Org. Geochem. 11, 513-527. doi:10.1016/0146-6380(87)90007-6

DeLeon, I. R., Maberry, M. A., Overton, E. B., Raschke, C. K., Remele, P. C., Steele, C. F., et al. (1980). Rapid Gas Chromatographic Method for the Determination of Volatile and Semivolatile Organochlorine Compounds in Soil and Chemical Waste Disposal Site Samples. J. Chromatogr. Sci. 18, 85-88. doi:10.1093/ chromsci/18.2.85

Didyk, B. M., Simoneit, B. R. T., Brassell, S. C., and Eglinton, G. (1978). Organic Geochemical Indicators of Palaeoenvironmental Conditions of Sedimentation. Nature 272, 216-222. doi:10.1038/272216a0

Ding, X., Liu, K., Gong, G., Tian, L., and Ma, J. (2020). Volatile Organic Compounds in the Salt-lake Sediments of the Tibet Plateau Influence Prokaryotic Diversity and Community Assembly. Extremophiles 24, 307-318. doi:10.1007/s00792-020-01155-3

Domagalski, J. L., Orem, W. H., and Eugster, H. P. (1989). Organic Geochemistry and Brine Composition in Great Salt, Mono, and Walker Lakes. Geochimica et Cosmochimica Acta 53, 2857-2872. doi:10.1016/0016-7037(89)90163-4

Dong, H., Zhang, G., Jiang, H., Yu, B., Chapman, L. R., Lucas, C. R., et al. (2006). Microbial Diversity in Sediments of Saline Qinghai Lake, China: Linking Geochemical Controls to Microbial Ecology. Microb. Ecol. 51 (1), 65-82. doi:10.1007/s00248-005-0228-6

Dorador, C., Fink, P., Hengst, M., Icaza, G., Villalobos, A. S., Vejar, D., et al. (2018). Microbial community composition and trophic role along a marked salinity gradient in Laguna Puilar, Salar de Atacama, Chile. Antonie van Leeuwenhoek 111, 1361-1374. doi:10.1007/s10482-018-1091-z

Dudareva, N., Klempien, A., Muhlemann, J. K., and Kaplan, I. (2013). Biosynthesis, Function and Metabolic Engineering of Plant Volatile Organic Compounds. New Phytol. 198, 16-32. doi:10.1111/nph.12145

Ellis, P. A., and Rivett, M. O. (2007). Assessing the Impact of VOC-Contaminated Groundwater on Surface Water at the City Scale. J. Contaminant Hydrol. 91, 107-127. doi:10.1016/j.jconhyd.2006.08.015

Eskanazy, G., Finkelman, R. B., and Chattarjee, S. (2010). Some Considerations Concerning the Use of Correlation Coefficients and Cluster Analysis in Interpreting Coal Geochemistry Data. Int. J. Coal Geology. 83, 491-493. doi:10.1016/j.coal.2010.05.006 
Evans, R., and Kirkland, D. W. (1988). Evaporitic Environments as a Source of Petroleum. Evaporites and hydrocarbons, 256-299. doi:10.7312/schr91060-006

Fry, B., and Sherr, E. B. (1989). " $\delta 13 C$ Measurements as Indicators of Carbon Flow in Marine and Freshwater Ecosystems," in Stable Isotopes in Ecological Research (New York, NY: Springer), 196-229. doi:10.1007/978-1-4612-3498-2_12

Galaktionova, E., Safarova, V., Kudasheva, F., and Teplova, G. (2012). Determination of Organic Compounds in Bottom Sediments by Gas Chromatography/mass Spectrometry Coupled with Static Headspace Analysis. J. Anal. Chem. 67 (6), 555-559. doi:10.1134/s1061934812060020

Gao, C., Deng, X., Zhang, K., Wang, L., and Xia, J. (2010). Research on Extracting boron from Brine by Centrifugal Extraction Method. J. salt lake Res. 18, 26-31.

Gao, S., Xu, B., Wang, J., and Cong, Z. (2019). Measuring Total Organic Carbon Precisely in lake Sediment in Tibetan Plateau by TOC Analyzer. Chin. J. Anal. Lab. 38, 413-416. doi:10.13595/j.cnki.issn1000-0720.2018.07250

Garrido-Delgado, R., Dobao-Prieto, M. d. M., Arce, L., and Valcárcel, M. (2015). Determination of Volatile Compounds by GC-IMS to Assign the Quality of virgin Olive Oil. Food Chem. 187, 572-579. doi:10.1016/ j.foodchem.2015.04.082

Gazley, M. F. F., Collins, K. S. S., Hines, B. R. R., Fisher, L. A. A., and McFarlane, A. (2015). "Application of Principal Component Analysis and Cluster Analysis to mineral Exploration and Mine Geology and Cluster Analysis to mineral Exploration," in AusIMM New Zealand Branch Annual Conference 2015, New Zealand, 131-139.

Gentle, J. E., Kaufman, L., and Rousseuw, P. J. (1991). Finding Groups in Data: An Introduction to Cluster Analysis. Biometrics 47, 788. doi:10.2307/2532178

Han, D., Ma, W., and Chen, D. (2007). Determination of Biodegradation Process of Benzene, Toluene, Ethylbenzene and Xylenes in Seabed Sediment by Purge and Trap Gas Chromatography. Chroma 66 (11), 899-904. doi:10.1365/s10337007-0434-0

Han, X., Schubert, C., Fiskal, A., Dubois, N., and Lever, M. (2020). "Lake Trophic States Shape Microbial Community Structure in Sediments," in EGU General Assembly Conference Abstracts, 9772, Vienna, Austria.

Hoffmann, K., Bienhold, C., Buttigieg, P. L., Knittel, K., Laso-Pérez, R., Rapp, J. Z., et al. (2020). Diversity and Metabolism of Woeseiales Bacteria, Global Members of marine Sediment Communities. Isme J. 14 (4), 1042-1056. doi:10.1038/ s41396-020-0588-4

Insam, H., and Seewald, M. S. A. (2010). Volatile Organic Compounds (VOCs) in Soils. Biol. Fertil. Soils 46, 199-213. doi:10.1007/s00374-010-0442-3

Isaji, Y., Kawahata, H., Ogawa, N. O., Kuroda, J., Yoshimura, T., Jiménez-Espejo, F. J., et al. (2019). Efficient Recycling of Nutrients in Modern and Past Hypersaline Environments. Sci. Rep. 9, 3718. doi:10.1038/s41598-019-40174-9

Jellison, R., Anderson, R. F., Melack, J. M., and Heil, D. (1996). Organic Matter Accumulation in Sediments of Hypersaline Mono Lake during a Period of Changing Salinity. Limnol. Oceanogr. 41, 1539-1544. doi:10.4319/ lo.1996.41.7.1539

Kawamura, K., and Nissenbaum, A. (1992). High Abundance of Low Molecular Weight Organic Acids in Hypersaline spring Water Associated with a Salt Diapir. Org. Geochem. 18, 469-476. doi:10.1016/0146-6380(92)90109-B

Keil, R. G., Tsamakis, E., Fuh, C. B., Giddings, J. C., and Hedges, J. I. (1994). Mineralogical and Textural Controls on the Organic Composition of Coastal marine Sediments: Hydrodynamic Separation Using SPLITT-Fractionation. Geochimica et Cosmochimica Acta 58, 879-893. doi:10.1016/0016-7037(94) 90512-6

Kesselmeier, J., Kuhn, U., Wolf, A., Andreae, M. O., Ciccioli, P., Brancaleoni, E., et al. (2000). Atmospheric Volatile Organic Compounds (VOC) at a Remote Tropical forest Site in central Amazonia. Atmos. Environ. 34, 4063-4072. doi:10.1016/S1352-2310(00)00186-2

Kidanu, W. G., Trang, P. T., and Yoon, H. H. (2017). Hydrogen and Volatile Fatty Acids Production from marine Macroalgae by Anaerobic Fermentation. Biotechnol. Bioproc. E 22, 612-619. doi:10.1007/s12257-017-0258-1

Kiene, R. P., and Taylor, B. F. (1988). Demethylation of Dimethylsulfoniopropionate and Production of Thiols in Anoxic Marine Sediments. Appl. Environ. Microbiol. 54, 2208-2212. doi:10.1128/ aem.54.9.2208-2212.1988

Klinkhammer, G. P., and Lambert, C. E. (1989). Preservation of Organic Matter during Salinity Excursions. Nature 339, 271-274. doi:10.1038/339271a0

Korpi, A., Järnberg, J., and Pasanen, A.-L. (2009). Microbial Volatile Organic Compounds. Crit. Rev. Toxicol. 39, 139-193. doi:10.1080/10408440802291497
Kuráň, P., and Soják, L. (1996). Environmental Analysis of Volatile Organic Compounds in Water and Sediment by Gas Chromatography. J. Chromatogr. A 733, 119-141. doi:10.1016/0021-9673(95)01121-8

Lagaly, G., Ogawa, M., and Dékány, I. (2013). "Chapter 10.3 - Clay Mineral-Organic Interactions," in Developments in Clay Science. Editors F. Bergaya and G. Lagaly (Oxford, United Kingdom: Elsevier).

Lantsuzskaya, E. V., Krisilov, A. V., and Levina, A. M. (2015). Structure of the Cluster Ions of Ketones in the Gas Phase According to Ion Mobility Spectrometry and $\mathrm{Ab}$ Initio Calculations. Russ. J. Phys. Chem. 89, 1838-1842. doi:10.1134/S0036024415100179

Levin, M. N., and Lantsuzskaya, E. V. (2014). Identification of Volatile Organic Compounds by Retention Times and Ion Mobility Spectra. J. Anal. Chem. 69 (12), 1153-1158. doi:10.1134/S1061934814120089

Li, M., Yang, R., Zhang, H., Wang, S., Chen, D., and Lin, S. (2019). Development of a Flavor Fingerprint by HS-GC-IMS with PCA for Volatile Compounds of Tricholoma Matsutake Singer. Food Chem. 290, 32-39. doi:10.1016/ j.foodchem.2019.03.124

Li, Y., Cai, J., Song, M., Ji, J., and Bao, Y. (2016). Influence of Organic Matter on Smectite Illitization: A Comparison between Red and Dark Mudstones from the Dongying Depression, China. Am. Mineral. 101, 134-145. doi:10.2138/am2016-5263

Liu, K., Ding, X., Tang, X., Wang, J., Li, W., Yan, Q., et al. (2018). Macro and Microelements Drive Diversity and Composition of Prokaryotic and Fungal Communities in Hypersaline Sediments and Saline-Alkaline Soils. Front. Microbiol. 9, 352. doi:10.3389/fmicb.2018.00352

Lomans, B. P., van der Drift, C., Pol, A., and Op den Camp, H. J. M. (2002). Microbial Cycling of Volatile Organic Sulfur Compounds. Cell Mol. Life Sci. CMLS 59 (4), 575-588. doi:10.1007/s00018-002-8450-6

McDonald, T. J., Kennicutt, M. C., and Brooks, J. M. (1988). Volatile Organic Compounds at a Coastal Gulf of Mexico Site. Chemosphere 17, 123-136. doi:10.1016/0045-6535(88)90050-1

Meyers, P. A. (2003). Applications of Organic Geochemistry to Paleolimnological Reconstructions: a Summary of Examples from the Laurentian Great Lakes. Org. Geochem. 34, 261-289. doi:10.1016/s0146-6380(02)00168-7

Meyers, P. A., and Ishiwatari, R. (1993). Lacustrine Organic Geochemistry-An Overview of Indicators of Organic Matter Sources and Diagenesis in lake Sediments. Org. Geochem. 20, 867-900. doi:10.1016/0146-6380(93)90100-P

Mohnke, M., and Buijten, J. (1993). Trace Analysis of Volatile Halogenated Hydrocarbons in Water. Chromatographia 37, 51-56. doi:10.1007/BF02272188

O'Leary, M. H. (1993). "Biochemical Basis of Carbon Isotope Fractionation," in Stable Isotopes and Plant Carbon-Water Relations. Editors J.R. Ehleringer, A.E. Hall, and G.D. Farquhar (San Diego: Academic Press).

Pearson, A., and Eglinton, T. I. (2000). The Origin of N -alkanes in Santa Monica Basin Surface Sediment: a Model Based on Compound-specific $\Delta 14 \mathrm{C}$ and $\delta 13$ C Data. Org. Geochem. 31, 1103-1116. doi:10.1016/S0146-6380(00)00121-2

Pecoraino, G., Scalici, L., Avellone, G., Ceraulo, L., Favara, R., Candela, E. G., et al. (2008). Distribution of Volatile Organic Compounds in Sicilian Groundwaters Analysed by Head Space-Solid Phase Micro Extraction Coupled with Gas Chromatography Mass Spectrometry (SPME/GC/MS). Water Res. 42, 3563-3577. doi:10.1016/j.watres.2008.07.022

Qingsheng, L., and Fengqing, H. (2013). Geological Characteristics and Lithium Distribution of East Taijinar Salt Lake in Qaidam Basin. J. salt lake Res. 21 (03), 1-9.

Ren, Z., Wang, F., Qu, X., Elser, J. J., Liu, Y., and Chu, L. (2017). Taxonomic and Functional Differences between Microbial Communities in Qinghai Lake and its Input Streams. Front. Microbiol. 8. doi:10.3389/fmicb.2017.02319

Rinnan, R., Steinke, M., Mcgenity, T., and Loreto, F. (2014). Plant Volatiles in Extreme Terrestrial and marine Environments. Plant Cell Environ 37, 1776-1789. doi:10.1111/pce.12320

Rodríguez-Maecker, R., Vyhmeister, E., Meisen, S., Rosales Martinez, A., Kuklya, A., and Telgheder, U. (2017). Identification of Terpenes and Essential Oils by Means of Static Headspace Gas Chromatography-Ion Mobility Spectrometry. Anal. Bioanal. Chem. 409, 6595-6603. doi:10.1007/s00216-017-0613-2

Sattler, T., Krause, T., Schöler, H., Kamilli, K., and Held, A. (2013). "Salt Lakes of Western Australia - Emissions of Natural Volatile Organic Compounds," in Egu General Assembly Conference, Vienna, Austria.

Serebrennikova, O. V., Strel'nikova, E. B., Duchko, M. A., Kadychagov, P. B., and Russkikh, I. V. (2015). Org. Matter Chemistry in Bottom Sediments of 
Freshwater and Salt Lakes in Southern Siberia. Water Resour. 42, 798-809. doi:10.1134/S0097807815060093

Shen, J. (2010). Lake Deposition and Environmental Evolution. Beijing, China: Science Press.

Siegrist, R. L., and Jenssen, P. D. (1990). Evaluation of Sampling Method Effects on Volatile Organic Compound Measurements in Contaminated Soils. Environ. Sci. Technol. 24, 1387-1392. doi:10.1021/es00079a013

Song, Q., Xu, B., Li, X., Li, W., and Qian, G. (2011). Identifi Cation of Volatile and Semivolatile Organic Compounds in Salt Lake Brine. American Lab. 43, 41-45.

Strehse, R., Bohne, H., Amha, Y., and Leinweber, P. (2018). The Influence of Salt on Dissolved Organic Matter from Peat Soils. Org. Geochem. 125, 270-276. doi:10.1016/j.orggeochem.2018.10.001

Susaya, J., Kim, K.-H., and Chang, Y.-S. (2011). Characterization of Major Offensive Odorants Released from lake Sediment. Atmos. Environ. 45 (6), 1236-1241. doi:10.1016/j.atmosenv.2010.12.010

Tazi, L., Breakwell, D. P., Harker, A. R., and Crandall, K. A. (2014). Life in Extreme Environments: Microbial Diversity in Great Salt Lake, Utah. Extremophiles 18, 525-535. doi:10.1007/s00792-014-0637-x

Thiros, S. a. (2000). Analysis of Nitrate and Volatile Organic Compound Data for Ground Water in the Great Salt Lake Basins, Utah, Idaho, and Wyoming, 198098. Water-Resources Investigations Report 2000-4043, 1-20. (Accessed 1997).

Thược, Đ. V., and Vóc, N. T. (2016). Isolation of Halophilic Bacterial Strains from Mangrove Soil Samples for Polyhydroxyalkanoate Production. VNU J. Sci. Nat. Sci. Tech. 32 (1).

Visscher, P. T., Baumgartner, L. K., Buckley, D. H., Rogers, D. R., Hogan, M. E., Raleigh, C. D., et al. (2003). Dimethyl Sulphide and Methanethiol Formation in Microbial Mats: Potential Pathways for Biogenic Signatures. Environ. Microbiol. 5, 296-308. doi:10.1046/j.1462-2920.2003.00418.x

Wang, X.-C., and Lee, C. (1993). Adsorption and Desorption of Aliphatic Amines, Amino Acids and Acetate by clay Minerals and marine Sediments. Mar. Chem. 44, 1-23. doi:10.1016/0304-4203(93)90002-6

Whelan, J. K. (1984). "Volatile C1-C8 Compounds in Marine Sediments," in Gas Chromatography Mass Spectrometry Applications in Microbiology. Editors G. Odham, L. Larsson, and P.-A. Mårdh (Boston, MA: Springer US).

Wu, X., Wang, Z., and He, Z. (2012). Implications of TS/TOC for Sedimentary Environments of the Southern Changjiang delta plain. J. Palaeogeogr. 14, 821-828.

Xu, Y., Cheung, W., Winder, C. L., and Goodacre, R. (2010). VOC-based Metabolic Profiling for Food Spoilage Detection with the Application to Detecting Salmonella Typhimurium-Contaminated Pork. Anal. Bioanal. Chem. 397, 2439-2449. doi:10.1007/s00216-010-3771-Z

Yang, X., Maotang, Cai., Hu, J., Ye, P., Ji, F., Zhang, Z., et al. (2020). The Paleolake Hydrology and Climate Change since the $\sim 40 \mathrm{Ka}$ in the Hetao Basin, Inner Mongolia, China. Quat. Int. 553, 73-82. doi:10.1016/j.quaint.2020.06.040

Yao, W., Shi, J., Qi, H., Yang, J., Jia, L., and Pu, J. (2011). Study on the Phytoplankton in Qinghai Lake during Summer of 2006-2010. Freshw. Fish. 41 (3), 22-28. doi:10.3969/j.issn.1000-6907.2011.03.004

Young, E. F., and Holt, J. T. (2007). Prediction and Analysis of Long-Term Variability of Temperature and Salinity in the Irish Sea. J. Geophys. Res. Oceans 112 (C1). doi:10.1029/2005jc003386
Yuan, Z.-y., Qu, H.-y., Xie, M.-z., Zeng, G., Huang, H.-y., Ren, F., et al. (2019) Direct Authentication of Three Chinese Materia Medica Species of the Lilii Bulbus Family in Terms of Volatile Components by Headspace-Gas Chromatography-Ion Mobility Spectrometry. Anal. Methods 11, 530-536. doi:10.1039/c8ay02338g

Zhang, P., Yu, S., Zhi, X., Zheng, X., Li, J., Li, B., et al. (1987). Salt Lake in Qaidam Basin. Beijing: Science Press.

Zhang, Y., Alam, M. A., Kong, X., Wang, Z., Li, L., Sun, Y., et al. (2017). Effect of Salinity on the Microbial Community and Performance on Anaerobic Digestion of marine Macroalgae. J. Chem. Technol. Biotechnol. 92, 2392-2399. doi:10.1002/jctb.5246

Zhao, J., Jin, Z., Jin, Z., Hu, Q., Hu, Z., Du, W., et al. (2017a). Mineral Types and Organic Matters of the Ordovician-Silurian Wufeng and Longmaxi Shale in the Sichuan Basin, China: Implications for Pore Systems, Diagenetic Pathways, and Reservoir Quality in fine-grained Sedimentary Rocks. Mar. Pet. Geology. 86, 655-674. doi:10.1016/j.marpetgeo.2017.06.031

Zhao, J., Jin, Z., Jin, Z., Wen, X., and Geng, Y. (2017b). Origin of Authigenic Quartz in Organic-Rich Shales of the Wufeng and Longmaxi Formations in the Sichuan Basin, South China: Implications for Pore Evolution. J. Nat. Gas Sci. Eng. 38, 21-38. doi:10.1016/j.jngse.2016.11.037

Zhao, M., Dupont, L., Eglinton, G., and Teece, M. (2003). n-Alkane and Pollen Reconstruction of Terrestrial Climate and Vegetation for N.W. Africa over the Last 160 Kyr. Org. Geochem. 34, 131-143. doi:10.1016/S0146-6380(02) 00142-0

Zhao, Q., Li, S., ZhenHe, W., Gong, J., Xiao, G., and Wu, L. (2016). Geochemical Characteristics of Jurassic Source Rocks from Well LV and Oil-Source Correlation in North Yellow Basin. Acta Sedimentologica Sinica 34, 794-802. doi:10.5194/bg-13-1635-2016

Zheng, M., and Liu, X. (2009). Hydrochemistry of Salt Lakes of the QinghaiTibet Plateau, China. Aquat. Geochem. 15, 293-320. doi:10.1007/s10498-0089055-y

Zhu, G., Jin, Q., Zhang, S., ZhanG, L., and Guo, C. (2004). Salt lake-saline lake Sedimentary Combination and Petroleum Accumulation in the Bonan Sag. Acta Mineralogica Sinica, 24 (01), 25-30. doi:10.16461/j.cnki.10004734.2004.01.005

Zuo, Z.-J., Zhu, Y.-R., Bai, Y.-L., and Wang, Y. (2012). Volatile Communication between Chlamydomonas Reinhardtii Cells under Salt Stress. Biochem. Syst. Ecol. 40, 19-24. doi:10.1016/j.bse.2011.09.007

Conflict of Interest: The authors declare that the research was conducted in the absence of any commercial or financial relationships that could be construed as a potential conflict of interest.

Copyright $\odot 2021 \mathrm{Lu}, \mathrm{Ma}$, Yi, Zhang, Chen and Han. This is an open-access article distributed under the terms of the Creative Commons Attribution License (CC BY). The use, distribution or reproduction in other forums is permitted, provided the original author(s) and the copyright owner(s) are credited and that the original publication in this journal is cited, in accordance with accepted academic practice. No use, distribution or reproduction is permitted which does not comply with these terms. 